\title{
Cyclin-Dependent Kinase 5 in the Ventral Tegmental Area Regulates Depression-Related Behaviors
}

\author{
Peng Zhong, ${ }^{1}$ Xiaojie Liu, ${ }^{1}$ Zhen Zhang, ${ }^{1,3}$ Ying Hu, ${ }^{1}$ Sarah J. Liu, ${ }^{1}$ Martha Lezama-Ruiz, ${ }^{1}$ Milan Joksimovic, ${ }^{2}$ \\ and Qing-song Liu ${ }^{1}$ \\ ${ }^{1}$ Department of Pharmacology and Toxicology and 2Department of Cell Biology, Neurobiology and Anatomy, Medical College of Wisconsin, Milwaukee, \\ Wisconsin 53226, and '3 Department of Geriatrics, Qi-Lu Hospital of Shandong University, Key Laboratory of Proteomics of Shandong Province, Jinan, \\ Shandong, China
}

\begin{abstract}
Dopamine neurons in the ventral tegmental area (VTA) govern reward and motivation and dysregulated dopaminergic transmission may account for anhedonia and other symptoms of depression. Cyclin-dependent kinase 5 (Cdk5) is a proline-directed serine/threonine kinase that regulates a broad range of brain functions through phosphorylation of a myriad of substrates, including tyrosine hydroxylase $(\mathrm{TH})$, the rate-limiting enzyme for dopamine synthesis. We investigated whether and how Cdk5 activity in VTA dopamine neurons regulated depression-related behaviors in mice. Using the Cre/LoxP system to selectively delete Cdk5 in the VTA or in midbrain dopamine neurons in $\mathrm{Cdk} 5{ }^{\text {loxP/loxP }}$ mice, we showed that Cdk5 loss of function in the VTA induced anxiety-and depressive-like behaviors that were associated with decreases in TH phosphorylation at Ser31 and Ser40 in the VTA and dopamine release in its target region, the nucleus accumbens. The decreased phosphorylation of $\mathrm{TH}$ at Ser 31 was a direct effect of $\mathrm{Cdk} 5$ deletion, whereas decreased phosphorylation of $\mathrm{TH}$ at Ser40 was likely caused by impaired cAMP/protein kinase A (PKA) signaling, because Cdk5 deletion decreased cAMP and phosphorylated cAMP response element-binding protein (p-CREB) levels in the VTA. Using Designer Receptors Exclusively Activated by Designer Drugs (DREADD) technology, we showed that selectively increasing cAMP levels in VTA dopamine neurons increased phosphorylation of TH at Ser 40 and CREB at Ser133 and reversed behavioral deficits induced by Cdk5 deletion. The results suggest that Cdk5 in the VTA regulates cAMP/PKA signaling, dopaminergic neurotransmission, and depression-related behaviors.
\end{abstract}

Key words: cAMP; Cdk5; depression; dopamine; DREADD; tyrosine hydroxylase

\section{Introduction}

The mesolimbic dopamine system governs the rewarding effects of food, sex, and social interaction, whereas poor appetite, anhedonia, lack of motivation, decreased sex drive, and social withdrawal are core symptoms of depression (Nestler and Carlezon, 2006). Patients with Parkinson's disease show high incidence (30-50\%) of comorbid depression (Burn, 2002). Deep brain stimulation of the nucleus accumbens (NAc) produces an acute relief of depressive symptoms in depressed patients (Schlaepfer et al., 2008). The $\mathrm{D}_{2}$ dopamine receptor and its signaling partners have been implicated in depressive-like behaviors (Bibb, 2005; Park et al., 2005). Distinct neuroadaptations in the ventral tegmental area (VTA)-NAc pathway confer susceptibility and resis-

Received Aug. 27, 2013; revised March 24, 2014; accepted April 1, 2014.

Author contributions: P.Z., M.J., and Q.L. designed research; P.Z., X.L., Y.H., Z.Z., S.J.L., and M.L.-R. performed research; M.J. contributed unpublished reagents/analytic tools; P.Z., X.L., Y.H., Z.Z., S.J.L., and M.L.-R. analyzed data; P.Z., M.J., and Q.L. wrote the paper.

This work was supported by the National Institutes of Health (Grants R21 MH095921 and R01 DA035217) and the Research and Education Initiative Fund, a component of the Advancing a Healthier Wisconsin endowment at the Medical College of Wisconsin. We thank Ming-Hu Han (Icahn School of Medicine at Mount Sinai) for critical reading of the manuscript.

The authors declare no competing financial interests.

Correspondence should be addressed to Qing-song Liu, PhD, Department of Pharmacology and Toxicology, Medical College of Wisconsin, 8701 Watertown Plank Road, Milwaukee, WI 53226. E-mail: qsliu@mcw.edu.

DOI:10.1523/JNEUROSCI.3673-13.2014

Copyright $\odot 2014$ the authors $\quad 0270-6474 / 14 / 346352-15 \$ 15.00 / 0$ tance to social defeat stress, an animal model of depression (Berton et al., 2006; Krishnan et al., 2007). Optogenetic stimulation and inhibition of VTA dopamine neurons modulate depression-related behaviors (Chaudhury et al., 2013; Tye et al., 2013). Dysfunction of dopaminergic transmission may underlie the manifestation of certain depressive symptoms.

Cyclin-dependent kinase $5(\mathrm{Cdk} 5)$ is a serine/threonine kinase that regulates many functions, including brain development, synaptic plasticity, cognition, learning, and memory, and dysfunction of Cdk5 has been implicated in neurodegenerative and neuropsychiatric diseases (Barnett and Bibb, 2011; Su and Tsai, 2011; Cheung and Ip, 2012). Recent studies have shown that forebrain Cdk5 activity regulates anxiety- and depressive-like behaviors. Mice with forebrain-specific deletion of $\mathrm{Cdk} 5$ in pyramidal neurons exhibit hyperactivity and reduced anxiety- and depressive-like behavior ( $\mathrm{Su}$ et al., 2013). Microinjection of a Cdk5 inhibitor into the dentate gyrus of rat hippocampus blocked depressive-like behavior induced by chronic mild stress (Zhu et al., 2012). A prominent function of Cdk5 is to modulate dopamine signaling in the brain. Cdk5 phosphorylates dopamine cyclic-AMP regulated phosphoprotein (DARPP-32), which allows DARPP-32 to become a protein kinase A (PKA) inhibitor and therefore a protein phosphatase 1 (PP1) activator (Bibb et al., 1999). Cdk5 also directly phosphorylates the $N$-terminal region of tyrosine hydroxylase (TH) at Ser31, the catalytic enzyme for 
Table 1. Experimental schedule for the sub-CUS or CUS procedure in mice

\begin{tabular}{|c|c|c|c|c|c|c|c|}
\hline Week & Monday & Tuesday & Wednesday & Thursday & Friday & Saturday & Sunday \\
\hline \multirow[t]{2}{*}{1} & Cold & Restraint & Light inversion & Cage rotation & Cold & Restraint & Light inversion \\
\hline & Wet bedding & No bedding & Cage tilt & Strobe & Food and water deprivation & Overcrowding & Wet bedding \\
\hline \multirow[t]{2}{*}{2} & Cold & Cage rotation & Restraint & Rat bedding & Light inversion & Cage rotation & Cold \\
\hline & Cage tilt & Food and water deprivation & Wet bedding & Strobe & No bedding & Food and water deprivation & Wet bedding \\
\hline \multirow[t]{2}{*}{3} & Rat bedding & Restraint & Cage rotation & Light inversion & Cold & Cage tilt & Light inversion \\
\hline & Strobe & Light inversion & No bedding & Food and water deprivation & Wet bedding & Strobe & Overcrowding \\
\hline \multirow[t]{2}{*}{4} & Cold & Restraint & Cage rotation & Rat bedding & Cold & Restraint & Cage rotation \\
\hline & No bedding & Food and water deprivation & Strobe & Light inversion & Cage tilt & Wet bedding & No bedding \\
\hline \multirow[t]{2}{*}{5} & Cold & Cage rotation & Light inversion & Cold & Cage rotation & Light inversion & Restraint \\
\hline & Food and water deprivation & Strobe & Wet bedding & Cage tilt & No bedding & Overcrowding & Cage tilt \\
\hline
\end{tabular}

Sub-CUS, Week 1; CUS, week 1 to week 5.

dopamine synthesis (Kansy et al., 2004; Moy and Tsai, 2004). Forebrain-specific Cdk5 knock-out mice exhibit enhanced neuronal excitability of NAc neurons, psychomotor-activating effects of cocaine, and food motivation (Benavides et al., 2007). Genetic deletion of the Cdk5 cofactor p35 in mice produces attention-deficit/hyperactivity disorder (ADHD) phenotype (Drerup et al., 2010) and ADHD is associated with perturbed dopaminergic neurotransmission (Tripp and Wickens, 2009). Because Cdk5 has intimate interaction with dopamine signaling system, Cdk5 activity in dopamine neurons may play a role in regulating anhedonia and other depression-related behaviors.

Here, we used a Cre/LoxP system to delete Cdk 5 in the VTA or in dopamine neurons and examined its impact on depression-related behavior. To selectively delete Cdk5 in the VTA, adeno-associated viral vectors (AAVs) carrying Cre recombinase were microinjected into the VTA of $\mathrm{Cdk} 5^{\text {loxP/loxP }}$ mice. Cdk5 was also conditionally deleted in dopamine neurons by breeding dopamine transporter (DAT)-Cre mice with Cdk $5^{\text {loxP/loxP }}$ mice. We examined the effects of loss of function of Cdk5 in the VTA on depression-related behaviors, TH phosphorylation, and dopamine release. Our results suggest that Cdk5 in the VTA regulates dopaminergic neurotransmission and depression-related behaviors.

\section{Materials and Methods}

Animals

Mice were given ad libitum access to food and water and housed $4-5$ per cage in a temperature-controlled $\left(23 \pm 1^{\circ} \mathrm{C}\right)$ and humidity-controlled $(40-$ $60 \%$ ) room with a $12 \mathrm{~h}$ light-dark cycle. Animal maintenance and use were in accordance with protocols approved by the Institutional Animal Care and Use Committee of the Medical College of Wisconsin. Homozygous Cdk5floxed mice (Cdk5 $5^{\text {loxP/loxP }}$, Jax stock \#014156), Cdk5 $5^{\text {wt/wt }}$ mice (Jax stock $\# 000664$ ), heterozygous DAT-Cre ${ }^{+/-}$mice (Jax stock \#006660) and ROSA26-flox-STOP-flox-lacZ (R26R) reporter mice (Jax stock \#003474) were obtained from The Jackson Laboratory. All of the mouse lines were maintained on the same C57BL/6 background. By crossing Cdk5 loxP/loxP mice with DAT-Cre ${ }^{+/-}$mice, we have generated a compound, DAT-Cre ${ }^{+/-}$/ $\mathrm{Cdk} 5^{\text {loxP/wt }}$ mouse line. We then crossed this compound, DAT-Cre ${ }^{+/-} /$ $\mathrm{Cdk} 5^{\text {loxP/wt }}$ mice with $\mathrm{Cdk} 5^{\text {loxP/loxP }}$ mice to create dopamine neuronspecific Cdk5 conditional knock-out (cKO) mice (DAT-Cre ${ }^{+/-} / \mathrm{Cdk} 5^{\text {loxP/loxP }}$ ). DAT-Cre ${ }^{-/-} / \mathrm{Cdk}^{\text {loxP/wt }}$ or DAT-Cre ${ }^{-/-} / \mathrm{Cdk} 5^{\text {loxP/loxP }}$ mice were used as experimental controls. All experiments were performed on adult male mice (8-14 weeks of age at the beginning of the experiments).

\section{Animal surgery and intra-VTA AAV microinjection}

AAV2-Cre-GFP and AAV2-GFP were obtained from the Penn Vector Core of University of Pennsylvania (Philadelphia, PA); AAV8-hSynDIO-rM3D-Gs-mCherry was obtained from University of North Carolina Vector Core Facilities (Chapel Hill, NC). Mice were anesthetized with ketamine $(90 \mathrm{mg} / \mathrm{kg}$, i.p.) and xylazine $(10 \mathrm{mg} / \mathrm{kg}$, i.p.) and placed in a stereotaxic device (David Kopf Instruments). AAVs (0.3 $\mu$ l per side) were bilaterally microinjected into the VTA via injector cannulae (33gauge; Plastics One), which were connected through C313C connectors to $2 \mu \mathrm{l}$ Hamilton microsyringes. The stereotaxic coordinates for VTA were as follows: anteroposterior, $-3.0 \mathrm{~mm}$; mediolateral, $\pm 1.0 \mathrm{~mm}$; dorsoventral, $-4.8 \mathrm{~mm}$ at a $7^{\circ}$ angle (Paxinos and Franklin, 2001). The injection rate was $0.3 \mu \mathrm{l}$ over $5 \mathrm{~min}$ and the injectors were kept in place for an additional $5 \mathrm{~min}$ to ensure adequate AAV diffusion from the injector tip. After the surgery, animals received subcutaneous injections of analgesic (buprenorphine, $0.05 \mathrm{mg} / \mathrm{kg}$ ) 3 times daily for $2 \mathrm{~d}$.

\section{Chronic unpredictable mild stress paradigm}

Mice were subjected to various chronic unpredictable mild stressors for 1 week (sub-CUS) or 5 weeks (CUS) based on published studies (Willner et al., 1987; Koo and Duman, 2008; Zhong et al., 2014). The stressors included restraint ( $1 \mathrm{~h}$ in a soft, flexible plastic cone, DecapiCone; Braintree Scientific), inversion of day/night light cycle, cold (in a cold room at $4^{\circ} \mathrm{C}$ for $1 \mathrm{~h}$ ), $45^{\circ}$ tilted cage (overnight), cage rotation $(20 \mathrm{~min}$ ), rat bedding (odor, $3 \mathrm{~h}$ ), wet bedding ( $250 \mathrm{ml}$ of water added into cage, overnight) and no bedding (overnight), low-intensity stroboscopic illumination $(10 \mathrm{~Hz}$, overnight), food and water deprivation (overnight), and overcrowding (overnight). On average, two stressors were administered per day. The timeline of the stressor exposure is described in Table 1. For stressed animals, cages were changed after "wet bedding," "no bedding," and "rat bedding" stressors. Nonstressed controls were handled only for cage changes and behavioral tests.

\section{Behavior}

Open field test. For the open field test (OFT), mice were placed individually in one corner of the open field $(50 \mathrm{~cm}$ length $\times 45 \mathrm{~cm}$ wide $\times 30 \mathrm{~cm}$ deep box) and allowed to freely explore the arena during a $20 \mathrm{~min}$ test session. Locomotor activities were recorded using an automated videotracking system (Mobile Datum). Total distance traveled and time spent in the center of the box during first $5 \mathrm{~min}$ were calculated. Time in center (center time) was defined as the amount of time that was spent in the central $25 \mathrm{~cm} \times 22.5 \mathrm{~cm}$ area of the open field.

Sucrose preference test. For the sucrose preference test (SPT), mice were individually housed and trained to drink from two drinking bottles for $48 \mathrm{~h}$. One bottle contained $1 \%$ sucrose (in tap water) and the other contained tap water. The SPT was performed after the OFT (see Figs. 2, 5, 11). During the SPT, mice were deprived of food and water for $8 \mathrm{~h}$ and the consumption of sucrose solution and water over the next $16 \mathrm{~h}$ was measured. The sucrose preference was calculated as sucrose solution consumed divided by the total amount of solution consumed (i.e., a percentage).

Elevated plus maze. The elevated plus maze (EPM) apparatus (Stoelting) comprises 2 open arms $(35 \times 5 \mathrm{~cm})$ across from each other and perpendicular to 2 closed arms $(35 \times 5 \times 15 \mathrm{~cm})$ that are connected by a center platform $(5 \times 5 \mathrm{~cm})$. It was elevated $40 \mathrm{~cm}$ above the floor. Mice were placed in the center platform facing a closed arm and allowed to freely explore the maze for $5 \mathrm{~min}$. The location of the mice was tracked with the automated video-tracking system. The number of entries and time spent in open arms were analyzed.

Novelty-suppressed feeding. The novelty-suppressed feeding (NSF) test was performed similar to a published protocol (Santarelli et al., 2003). Mice were deprived of food for $24 \mathrm{~h}$ before being placed in a novel environment (a plastic box $45 \mathrm{~cm}$ long $\times 35 \mathrm{~cm}$ wide $\times 20 \mathrm{~cm}$ deep) 
where 5 food pellets (regular chow) were placed on a piece of white filter paper $(11 \mathrm{~cm}$ in diameter) in the center of the box. A mouse was placed in one corner of the box and the latency to feed was measured. Feeding was defined as biting the food using forepaws, not simply sniffing or touching the food. Immediately after the test, the animal was transferred to the home cage and the latency to feed in the home cage was measured to serve as controls.

Forced swim test. For the forced swim test (FST), mice were placed individually into glass cylinders $(13 \mathrm{~cm}$ diameter, $25 \mathrm{~cm}$ tall) filled to a depth of $18 \mathrm{~cm}$ with water $\left(25 \pm 1^{\circ} \mathrm{C}\right)$. The mice were placed in the cylinders for $6 \mathrm{~min}$. The time spent immobile during the last $4 \mathrm{~min}$ was scored. Immobility was defined as the cessation of all movements (e.g., climbing, swimming) except those necessary for the mouse to keep its head above water (i.e., floating).

\section{Western blotting}

Experimental procedure was conducted as we have described previously (Pan et al., 2011; Yu et al., 2013). Mice were anesthetized with isoflurane and rapidly decapitated. Brains were sliced in a $1 \mathrm{~mm}$ matrix (Zivic Instruments) and the VTA was bilaterally punched out using 18 gauge blunt needles and immediately homogenized in $0.2 \mathrm{ml}$ of lysis buffer, $\mathrm{pH}$ 7.6, containing the following (in mM): 50 Tris-acetate, $50 \mathrm{NaF}, 10 \mathrm{EDTA}$, and 10 EGTA, along with $0.01 \%$ Triton X-100, protease inhibitors (Research Product International), and protein phosphatase inhibitors I and II (Sigma-Aldrich). After centrifugation at $1000 \times \mathrm{g}$ for $10 \mathrm{~min}$, total protein concentration of the supernatant was assayed using a Bio-Rad protein assay kit. The concentration of protein was calibrated to 1 or 2 $\mu \mathrm{g} / \mu \mathrm{l}$ with $2 \times$ loading buffer containing $0.1 \mathrm{~m}$ Tris- $\mathrm{HCl}, \mathrm{pH} 6.8,4 \%$ $(\mathrm{w} / \mathrm{v})$ SDS, $20 \%(\mathrm{v} / \mathrm{v})$ glycerol, $10 \%(\mathrm{v} / \mathrm{v}) 2$-mercaptoethanol, and $0.04 \%$ $(\mathrm{w} / \mathrm{v})$ bromophenol blue. Samples were separated in SDS-PAGE and transferred to PVDF membranes. Membranes were blocked in blocking buffer containing $5 \%(\mathrm{w} / \mathrm{v})$ milk and $0.1 \%(\mathrm{v} / \mathrm{v})$ Tween 20 in Trisbuffered saline (TBS-T) for $\sim 1-2 \mathrm{~h}$ at room temperature and incubated overnight at $4^{\circ} \mathrm{C}$ with antibodies against Cdk5 (mouse, 1:1000; Millipore), p35/25 (1:200; Santa Cruz Biotechnology), p-TH-Ser31 (1:200; R\&D Systems), p-TH-Ser40 (1:300; Millipore), TH (1:500; Santa Cruz Biotechnology), phosphorylated cAMP response element-binding protein ( p-CREB)-Ser133 (1:200; Cell Signaling Technology), CREB (1:200; Cell Signaling Technology), or GAPDH (1:1000; Cell Signaling Technology) antibodies. Membranes were washed 3 times with TBS-T and then probed with anti-mouse IgG, HRP-linked antibody (1:5000; Bio-Rad) or anti-rabbit IgG, HRP-linked antibody (1:3000; Cell Signaling Technology) for $2 \mathrm{~h}$ at room temperature before being developed using an ECL immunoblotting detection system (Thermo Scientific). Immunoreactivity of Western blots was quantified by densitometry using ImageJ software and normalized to GAPDH.

\section{cAMP ELISA}

The VTA sample collection was similar to the process described in the "Western Blotting" section. The VTA was dissected out bilaterally, frozen in liquid nitrogen, homogenized in ice-cold hydrochloric acid $(0.1 \mathrm{M})$, and centrifuged at $13,000 \times g$ for $50 \mathrm{~min}$ at $4^{\circ} \mathrm{C}$. cAMP in the supernatant was determined by direct cAMP ELISA kit (Enzo Life Sciences). The optical density was read at $405 \mathrm{~nm}$ using an ELX800 Universal Microplate Reader (Bio-TEK Instruments). Finally, the cAMP concentration was normalized to total protein, which was assayed using a Bio-Rad protein assay kit.

\section{Immunohistochemistry}

Mice were anesthetized with isoflurane and transcardially perfused with 0.1 m sodium PBS, followed by $4 \%$ paraformaldehyde in $4 \%$ sucrose$\mathrm{PBS}, \mathrm{pH}$ 7.4. After perfusion, the brain was removed and postfixed in the same fixative for $4 \mathrm{~h}$ at $4^{\circ} \mathrm{C}$ and was then dehydrated in increasing concentrations of sucrose ( $20 \%$ and $30 \%)$ in $0.1 \mathrm{M} \mathrm{PBS}$ at $4^{\circ} \mathrm{C}$ and frozen on dry ice. Coronal VTA sections were made at $20 \mu \mathrm{m}$ thickness with a cryostat.

$D A B$ staining. VTA Sections were incubated with antibodies against $\mathrm{TH}$ (1:300; Santa Cruz Biotechnology) or p-CREB-Ser133 (1:200; Cell Signaling Technology) at $4^{\circ} \mathrm{C}$ for $48 \mathrm{~h}$. After 3 washes with PBS, sections were then incubated with goat anti-rabbit IgG-HRP (1:100; Bio-Rad) for $2 \mathrm{~h}$ at room temperature. Immunoreactivity was visualized with $0.05 \% \mathrm{DAB}-0.004 \%$ $\mathrm{H}_{2} \mathrm{O}_{2}$ in $0.1 \mathrm{M}$ ammonium phosphate buffer (APB) for $10 \mathrm{~min}$, after which the reaction was stopped with APB for 5 min and then rinsed in PBS, dehydrated, and coverslipped. Sections were imaged with a Nikon Eclipse 80i microscope and analyzed by Image software. $\mathrm{TH}^{+}$cells or $\mathrm{p}-\mathrm{CREB}{ }^{+}$cells in the VTA were counted from the left and right side of the brain in 2 sections from each animal at $\sim 3.3 \mathrm{~mm}$ and $3.4 \mathrm{~mm}$ posterior to bregma. The coordinates were determined by comparing the brain structures in the immunohistological sections with those in mouse stereotaxic atlas (Paxinos and Franklin, 2001). The number of $\mathrm{TH}^{+}$cells or $\mathrm{p}-\mathrm{CREB}^{+}$cells was normalized to the VTA area, which was determined with the aid of the same stereotaxic atlas.

Immunofluorescence staining. VTA sections were incubated with antibodies against $\beta$-galactosidase (chicken, 1:1000; Abcam), Cdk5 (rabbit, 1:100; Santa Cruz Biotechnology), and/or TH (mouse or rabbit, 1:300; Santa Cruz Biotechnology) at $4^{\circ} \mathrm{C}$ for $48 \mathrm{~h}$. Based on different host species of first antibodies, VTA sections were incubated in the different second antibodies: anti-chicken IgG Alexa Fluor 568 conjugate (1:1000; Life Technologies), anti-rabbit IgG-Texas red conjugate (1:200; Santa Cruz Biotechnology), or anti-mouse IgG-FITC conjugate (1:200; Santa Cruz Biotechnology) for $4 \mathrm{~h}$ at room temperature in the dark. The sections were analyzed using a Nikon Eclipse TE-2000U confocal microscope.

\section{Slice preparation and fast-scan cyclic voltammetry}

Mice were anesthetized by isoflurane inhalation and decapitated. Striatal slices containing the NAc $(250 \mu \mathrm{m})$ were prepared as described previously (Wang et al., 2010). Slices were prepared at $4-6^{\circ} \mathrm{C}$ in a solution containing the following (in mM): 220 sucrose, $2.5 \mathrm{KCl}, 1.25 \mathrm{NaH}_{2} \mathrm{PO}_{4}$, $0.5 \mathrm{CaCl}_{2}, 7 \mathrm{MgSO}_{4}, 26 \mathrm{NaHCO}_{3}, 10$ glucose, and 1 sodium ascorbate, and transferred to and stored in artificial CSF (ACSF) containing the following (in mM): $119 \mathrm{NaCl}, 2.5 \mathrm{KCl}, 2.5 \mathrm{CaCl}_{2}, 1 \mathrm{MgCl}_{2}, 1.25$ $\mathrm{NaH}_{2} \mathrm{PO}_{4}, 26 \mathrm{NaHCO}_{3}$, and 10 glucose at room temperature. All solutions were saturated with $95 \% \mathrm{O}_{2}$ and $5 \% \mathrm{CO}_{2}$.

To detect dopamine release with fast-scan cyclic voltammetry (FSCV), a glass-encased cylindrical carbon fiber ( $7 \mu \mathrm{m}$ diameter; Goodfellow) microelectrode with an exposed final length of $100-150 \mu \mathrm{m}$ was lowered into the NAc shell at approximate locations: anteroposterior, $0.9-1.7 \mathrm{~mm}$; mediolateral, $\pm 0.5 \mathrm{~mm}$; dorsoventral, $-4.4 \mathrm{~mm}$. The coordinates were determined by visual inspection of the slice with a mouse brain atlas (Paxinos and Franklin, 2001). The microelectrode was filled with the solution containing 150 $\mathrm{mm} \mathrm{KCl}$. Triangular waveforms (holding at $-0.4 \mathrm{~V}$, from $-0.4 \mathrm{~V}$ to $1.3 \mathrm{~V}$ at $400 \mathrm{~V} / \mathrm{s}$ ) were applied every $100 \mathrm{~ms}$ using Demon software (Yorgason et al., 2011) and a Chem-Clamp Potentiostat (Dagan). A stimulating electrode was placed at $\sim 100 \mu \mathrm{m}$ from the carbon fiber microelectrode and dopamine release was evoked by a single electrical stimulus pulse $(250 \mu \mathrm{A}, 0.1 \mathrm{~ms}$ duration) or a 5-pulse train stimuli at 10,30, and $50 \mathrm{~Hz}$. After the recordings, electrodes were calibrated in $0.1-1 \mu \mathrm{M}$ dopamine in the ACSF. Recordings were performed at $32 \pm 1^{\circ} \mathrm{C}$ using an automatic temperature controller (Warner Instrument).

\section{Chemicals}

Clozapine- $N$-oxide (CNO) was purchased from Enzo Life Sciences. All other common chemicals were purchased from Sigma-Aldrich.

\section{Data analysis and statistics}

All results are expressed as mean \pm SEM. Results were analyzed with Student's $t$ test or one-way or two-way ANOVA followed by Tukey's post hoc analysis. Results were considered to be significant at $p<0.05$.

\section{Results}

\section{VTA-specific deletion of Cdk5 produced depressive- like behaviors}

To assess the role of Cdk5 in the VTA in modulating depressionrelated behavior, we deleted the Cdk5 gene locally using AAV type 2 vector expressing green fluorescent protein (GFP)-tagged Cre recombinase (AAV2-Cre-GFP). To evaluate the effectiveness of the Cre recombinase in the AAV, we first injected AAV2-CreGFP or a control vector (AAV2-GFP) stereotaxically into the VTA (Fig. 1A) of R26R LacZ (gene encoding $\beta$-galactosidase) 
A
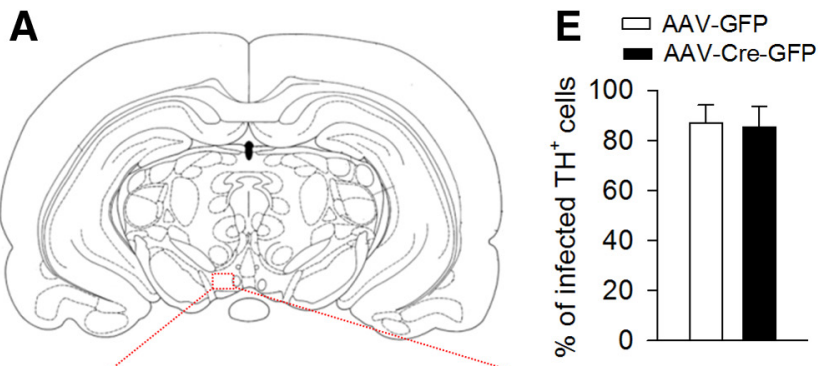

AAV-Cre-GFP-R26R LacZ reporter

B

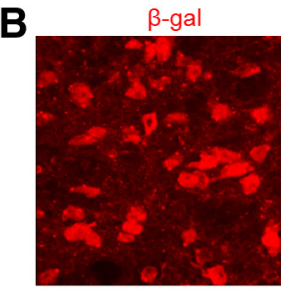

C

$\mathrm{TH}$

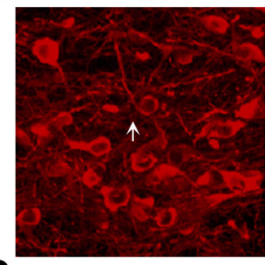

D

$\mathrm{TH}$
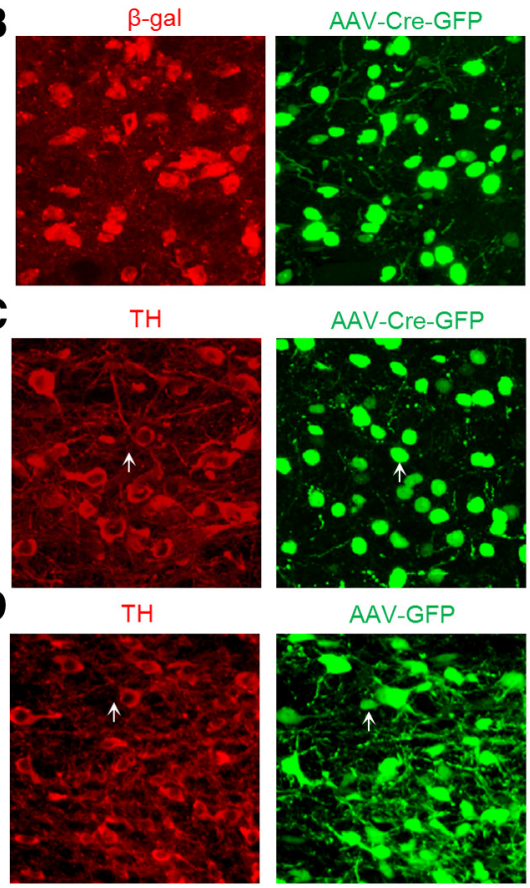

AAV-Cre-GFP

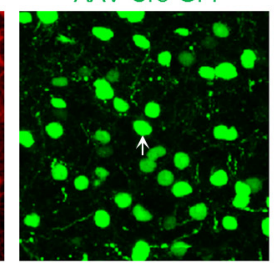

AAV-GFP

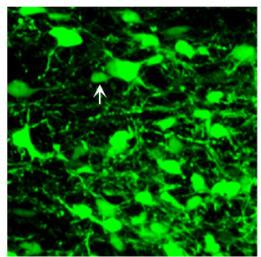

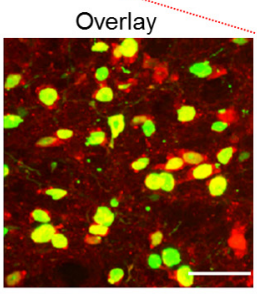

Overlay

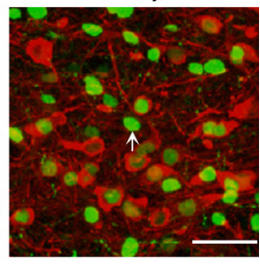

Overlay

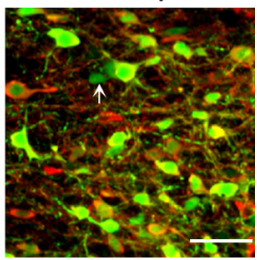

Figure 1. Injection of AAV2-Cre-GFP into the VTA of R26R LacZ reporter mice induced the expression of $\beta$-galactosidase. $\boldsymbol{A}$, Location of VTA injection. $\boldsymbol{B}$, Immunofluorescence labeling showed that $\beta$-galactosidase ( $\beta$-gal, red) was expressed in AAV2-Cre-GFP-infected neurons (green). $\boldsymbol{C}, \boldsymbol{D}, \mathrm{AAV} 2-\mathrm{Cre}-\mathrm{GFP}$ ( $\boldsymbol{C}$ ) or AAV2-GFP ( $\boldsymbol{D}$; green) was expressed in $\mathrm{TH}^{+}$(dopamine neuron marker, red) dopamine neurons in the VTA. In addition, a substantial number of $\mathrm{TH}^{-}$ nondopamine neurons were also infected by the AAVs (indicated by arrow). Scale bar, $50 \mu \mathrm{m}$. $\boldsymbol{E}$, Summarized data showed that AAV2-Cre-GFP or AAV2-GFP infected $\sim 85 \%$ of $\mathrm{TH}^{+}$dopamine neurons in the VTA ( $n=3$ mice/group). Error bars indicate SEM.

reporter mice carrying the reporter cassette in the ROSA 26 locus. After recovery for 3 weeks, immunofluorescence labeling showed that $\beta$-galactosidase was expressed in nearly all cells infected with AAV2-Cre-GFP (Fig. 1B). The fusion of Cre with GFP in the AAV2-Cre-GFP vector allowed Cre-GFP to be predominantly localized in the nucleus (Fig. $1 B, C$ ). Approximately $85 \%$ of dopamine neurons in the VTA were infected by the AAVs, as shown by coexpression of TH and GFP (Fig. $1 C-E$ ). Approximately $25 \%$ of GFP neurons were not colabeled with $\mathrm{TH}$, suggesting that a substantial number of nondopamine neurons were also infected by the AAVs (Fig. 1C,D). These results indicate that the AAV2delivered Cre recombinase is effective and can be used to delete $\mathrm{Cdk} 5$ in the VTA.

We then injected AAV2-Cre-GFP or AAV2-GFP into the VTA bilaterally in Cdk5-floxed mice homozygous for the loxP-Cdk5loxP sequence $\left(\mathrm{Cdk} 5^{\text {loxP/loxP }}\right)$. In an additional control experiment, AAV2-Cre-GFP was bilaterally injected into the VTA of $\mathrm{Cdk} 5^{\mathrm{wt} / \mathrm{wt}}$ mice. The timeline of the AAV injection, behavioral tests, immunofluorescence labeling, and Western blotting is

shown in Figure $2 A$. Three weeks after the AAV injection, we investigated whether Cdk5 deletion in the VTA affected depression- and anxiety-related behaviors. The OFT was used to determine whether VTA-specific deletion of Cdk5 affected locomotor activity and anxiety-related behavior. Reduced activity in the center of an open field has been correlated with anxiety- and depressive-like behaviors in rodents (El Yacoubi et al., 2003). We analyzed the total distance traveled and time spent in center (center time) in the OFT. A one-way ANOVA revealed that VTAspecific deletion of Cdk5 did not affect locomotor activity, as shown by the total distance traveled $\left(F_{(2,33)}=0.37, p=0.69\right)$, but significantly decreased the center time $\left(F_{(2,33)}=5.83, p=0.007\right.$; Fig. $2 B$ ). We then performed the SPT to assess anhedonia, a core symptom of depression (Duman, 2007). VTA-specific deletion of Cdk5 significantly decreased the sucrose preference $\left(F_{(2,33)}=\right.$ 6.14, $p=0.005$; Fig. 2C). We used the EPM test to evaluate anxiety-related behavior. A decrease in number of entries and the time spent in the open arms indicates anxiety-like behavior (Rodgers and Dalvi, 1997; Komada et al., 2008). However, neither the entries into the open $\operatorname{arms}\left(F_{(2,33)}=0.14, p=0.87\right)$ nor the time spent in the open arms $\left(F_{(2,33)}=0.75, p=0.48\right)$ was affected by VTA-specific deletion of Cdk5 (Fig. 2D). The NSF test is another test for depressive- and anxiety-like behavior (Santarelli et al., 2003). In the NSF test, a fasting mouse faces the choice between eating the food in the center of an open field and avoiding the novel environment. An increase in the latency to feed in the novel environment indicates anxiety-like behavior. VTA-specific deletion of Cdk5 significantly increased the latency to feed in the novel environment $\left(F_{(2,33)}=7.01, p=0.003\right)$, but did not alter the latency to feed in the home cage $\left(F_{(2,33)}=0.68, p=0.51\right.$; Fig. $2 E)$, suggesting that the Cdk5-deletion-induced change in the latency to feed in the novel environment in the NSF test cannot be explained by possible changes in appetite. Finally, we performed the FST, which has been used for screening behavioral effects of antidepressants (Porsolt et al., 1977). An increase in the immobility time in the FST suggests behavioral despair and depression. VTA-specific deletion of Cdk5 significantly increased the immobility time in the FST $\left(F_{(2,33)}=6.64, p=0.004\right.$; Fig. $\left.2 F\right)$. Therefore, VTA-specific deletion of Cdk5 induces depressive-like behaviors in most of the behavioral tests.

After the behavioral tests, mice were euthanized and Cdk5 protein expression was determined using immunofluorescence labeling and Western blotting. We found that Cdk5 was expressed in the VTA in Cdk $5^{\text {loxP/loxP }}$ mice that received intra-VTA injection of AAV2-GFP or in Cdk5 ${ }^{\mathrm{wt} / \mathrm{wt}}$ mice that received intraVTA injection of AAV2-Cre-GFP. However, Cdk5 was lost in the VTA in Cdk $5^{\text {loxP/loxP }}$ mice that received intra-VTA injection of AAV2-Cre-GFP (Fig. 3A-C). Western blotting analysis of VTA tissue samples showed that Cdk5 levels in the VTA were significantly decreased in $\mathrm{Cdk} 5^{\text {loxP/loxP }}$ mice that received AAV2-CreGFP injection compared with the other two groups $\left(F_{(2,15)}=\right.$ 15.65, $p<0.001$; Fig. 3D,E). VTA-specific deletion of Cdk5 did not alter the protein levels of Cdk5 cofactor p35 significantly $\left(F_{(2,15)}=0.06, p=0.94 ;\right.$ Fig. $\left.3 D, E\right) \cdot \mathrm{p} 25$, a truncated form of $\mathrm{p} 35$ (Patrick et al., 1999), was not detectable in VTA tissue samples (Fig. 3D). These results confirmed that AAV2-Cre-GFP was effective in deleting Cdk5 in the VTA and suggested that VTAspecific deletion of Cdk5 induced depressive-like behaviors.

Dopamine neuron-specific conditional knock-out of Cdk5 induced depressive-like behaviors

The VTA consists of mainly dopamine and GABAergic neurons (Johnson and North, 1992), so we next sought to determine the 


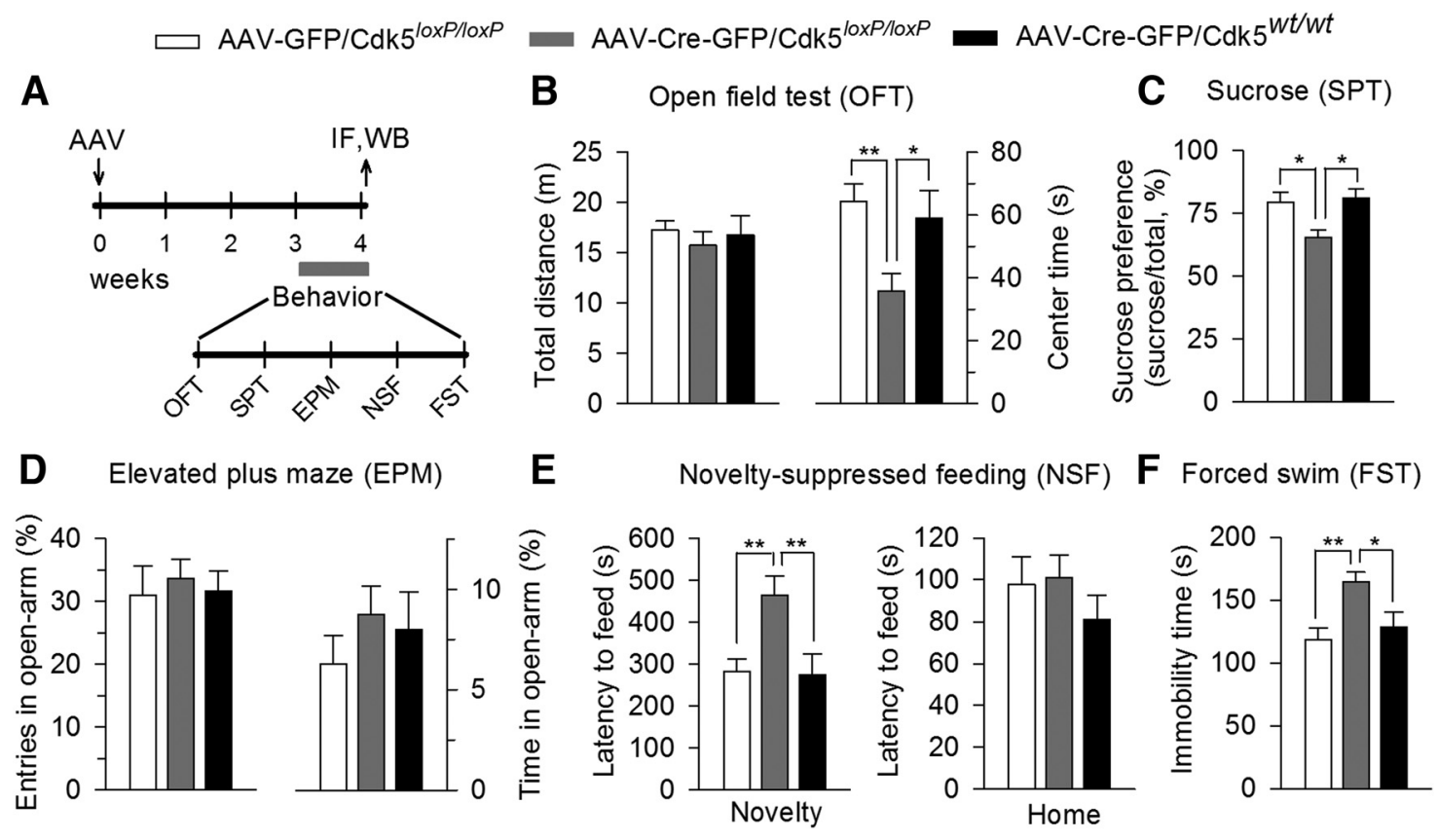

Figure 2. AAV2-Cre-GFP-mediated VTA-specific deletion of Cdk5 produced anxiety- and depressive-like behaviors in Cdk5 $5^{\text {loxP/loxP }}$ mice. Cdk5 ${ }^{\text {loxP/loxP }}$ mice received bilateral intra-VTA injection of AAV2-Cre-GFP. As control groups, Cdk5 loxP/loxP mice received AAV2-GFP injection or C $d 5^{\mathrm{wt} / \text { wt }}$ mice received AAV2-Cre-GFP injection. A, Timeline for the AAV microinjection, behavioral tests, immunofluorescence labeling (IF), and Western blotting (WB). B, VTA-specific deletion of Cdk5 (Cdk5 ${ }^{\text {loxP/loxP }}$ mice received bilateral intra-VTA injection of AAV2-Cre-GFP) significantly decreased the center time $(p<0.01)$ without affecting total distance traveled in the $0 \mathrm{FT}(p>0.05)$. C, Cdk5 deletion significantly decreased sucrose preference $(p<0.01)$. D, Cdk5 deletion did not affect the entries into the open arms $(p>0.05)$ and the time spent in the open arms $(p>0.05)$ in the EPM test. $E$, Cdk5 deletion increased the latency to feed in the novel environment (Novelty) in the NSF test $(p<0.01$ ), but did not significantly affect the latency to feed in the home cage (Home; $p>0.05)$. $\boldsymbol{F}$, (dk5 deletion increased the immobility time in FST ( $p<0.01$ ). The $p$ values for Tukey's post hoc test results are shown on the top ( ${ }^{*} p<0.05,{ }^{* *} p<0.01 ; n=10-13$ mice/group) for AAV, AAV2-Cre-GFP, and AAV2-GFP.

role of Cdk5 specifically in VTA dopamine neurons in regulating depression-related behavior. To delete Cdk5 selectively from dopamine neurons, we used DAT-Cre ${ }^{+/-}$mice that express Cre recombinase controlled by DAT promoter (Bäckman et al., 2006). We generated dopamine neuron-specific Cdk5 knock-out mice by crossing homozygous $\mathrm{Cdk} 5{ }^{\text {loxP/loxP }}$ mice with heterozygous DAT-Cre ${ }^{+1-}$ mice. Among the offspring generated, DAT$\mathrm{Cre}^{+/-} / \mathrm{Cdk} 5^{\text {loxP/loxP }}$ mice were used as the Cdk5 conditional knock-out $(\mathrm{Cdk} 5 \mathrm{cKO})$ group. DAT-Cre ${ }^{-1-} / \mathrm{Cdk} 5^{\text {loxP/loxP }}$ and DAT-Cre ${ }^{-1-} / \mathrm{Cdk} 5^{\text {loxP/wt }}$ mice were used as the control groups. The control and $\mathrm{Cdk} 5 \mathrm{cKO}$ mice were grossly normal. Immunohistochemical staining with $\mathrm{TH}$ did not detect any overt alterations in the gross morphology and total number of $\mathrm{TH}^{+}$ dopamine neurons in Cdk5 $\mathrm{cKO}$ mice compared with those in control mice $\left(t_{(22)}=0.29, p=0.78\right.$; Fig. $\left.4 A, B\right)$. In control mice, Cdk5 was expressed in both $\mathrm{TH}^{+}$dopamine neurons and $\mathrm{TH}^{-}$ nondopamine neurons. In Cdk5 cKO mice, Cdk5 and TH labeling were nonoverlapping and $\mathrm{Cdk} 5$ was expressed in $\mathrm{TH}^{-}$ neurons but was absent in $\mathrm{TH}^{+}$neurons (Fig. 4C). Western blotting analysis of VTA tissue samples showed that Cdk5 protein levels were significantly decreased in Cdk5 $\mathrm{cKO}$ mice $\left(t_{(10)}=\right.$ $3.68, p=0.004$; Fig. $4 D, E)$, whereas p35 protein levels were not significantly changed $\left(t_{(10)}=0.31, p=0.77\right.$; Fig. $\left.4 D, E\right)$. These data confirmed the effectiveness and specificity of Cdk5 deletion in dopamine neurons.

Next, we investigated whether conditional knock-out of Cdk5 in dopamine neurons affected depression-related behaviors. Behavioral tests shown in Figure 2 were performed in animals without prior stress exposure and such baseline responses do not reflect stress vulnerability, which could be more relevant to pathophysiology of depression. We therefore subjected control and Cdk5 cKO mice to sub-CUS and CUS (Willner et al., 1987;
Koo and Duman, 2008). Control and Cdk5 cKO mice were exposed to a variety of mild stressors in an unpredictable manner for 1 week (sub-CUS) or 5 weeks (CUS; Table 1) or were not subjected to any stressors (nonstressed). Two-way ANOVA showed that neither stress nor Cdk5 cKO altered locomotor activity, as shown by the total distance traveled (stress: $F_{(2,59)}=$ $0.86, p=0.43$; Cdk5 cKO: $F_{(1,59)}=0.38, p=0.54$; stress $\times$ Cdk5 cKO interaction: $\left.F_{(2,59)}=0.44, p=0.65\right)$ and center time (stress: $F_{(2,59)}=1.10, p=0.34$; Cdk5 cKO: $F_{(1,59)}=0.26, p=0.61$; stress $\times$ Cdk5 cKO interaction: $\left.F_{(2,59)}=0.51, p=0.60\right)$ in the OFT (Fig. 5A). In the SPT, stress and Cdk5 $\mathrm{cKO}$ had significant main effects on the sucrose preference (stress: $F_{(2,59)}=23.25, p<$ 0.001; Cdk5 cKO: $F_{(1,59)}=53.80, p<0.001$, stress $\times$ Cdk $5 \mathrm{cKO}$ interaction: $F_{(2,59)}=4.02, p=0.02$; Fig. $\left.5 B\right)$. Tukey's post hoc tests indicated that, in nonstressed groups, Cdk $5 \mathrm{cKO}$ mice exhibited a significant decrease in the baseline sucrose preference compared with wild-type control mice $(p=0.006)$. CUS ( $p<$ 0.001 ), but not sub-CUS ( $p=0.74$ ), significantly decreased the sucrose preference in wild-type control mice, whereas both subCUS $(p<0.001)$ and CUS $(p<0.001)$ further decreased the sucrose preference in $\mathrm{Cdk} 5 \mathrm{cKO}$ mice. These results indicate that $\mathrm{Cdk} 5 \mathrm{cKO}$ mice exhibited increased vulnerability to stress.

In the EPM test, stress, but not Cdk5 cKO, had significant main effects on the number of entries into the open arms (stress: $F_{(2,59)}=9.88, p<0.001$; Cdk5 cKO: $F_{(1,59)}=0.40, p=0.53$; stress $\times$ Cdk 5 cKO interaction: $\left.F_{(2,59)}=0.02, p=0.98\right)$ and the time spent in the open arms (stress: $F_{(2,59)}=4.26, p=0.02$; Cdk5 cKO: $F_{(1,59)}=0.08, p=0.78$; stress $\times \mathrm{Cdk} 5 \mathrm{cKO}$ interaction: $F_{(2,59)}=0.09, p=0.91$; Fig. $\left.5 C\right)$. In addition, CUS, but not sub-CUS, significantly decreased the number of entries in the open arms (nonstress vs CUS, $p<0.001$; nonstress vs sub-CUS, $p=0.51$ ) and the time spent in the open arms (nonstress vs CUS, 


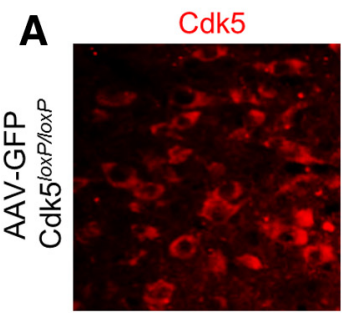

B
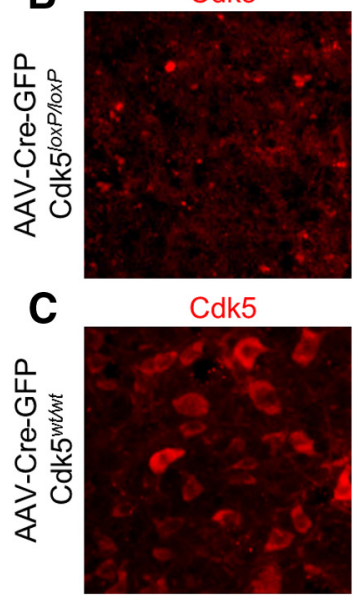

AAV-GFP

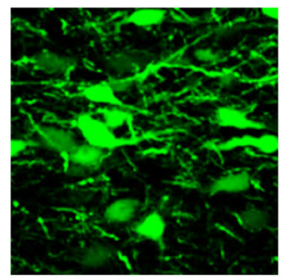

AAV-Cre-GFP

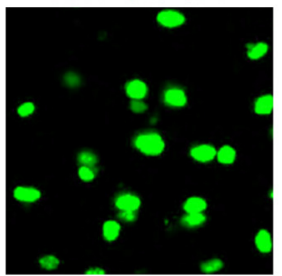

AAV-Cre-GFP

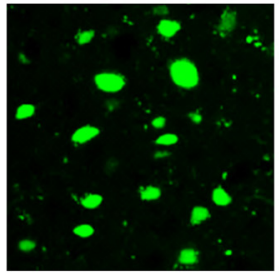

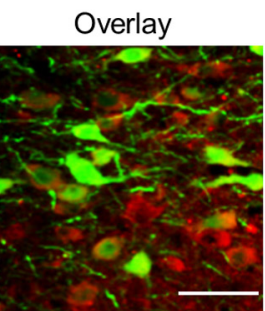

Overlay

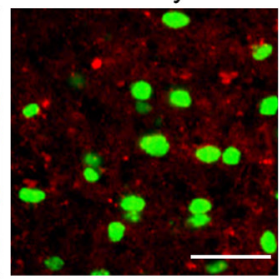

Overlay

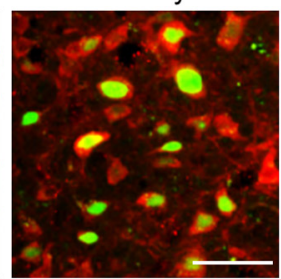

D

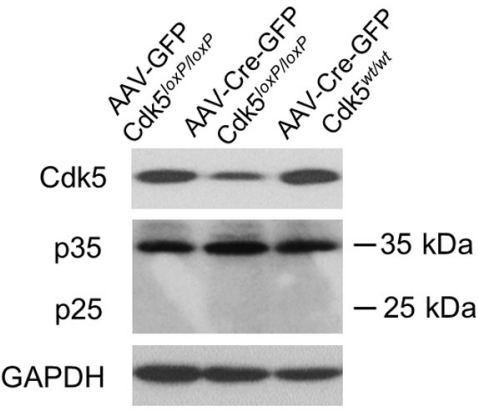

$\mathbf{E}$
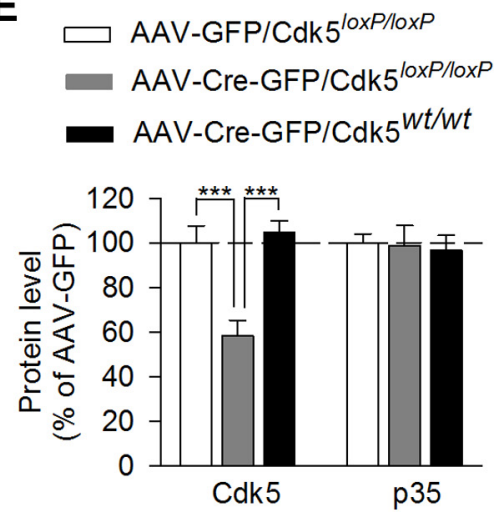

Figure 3. AAV2-Cre-GFP-mediated VTA-specific deletion of $C \mathrm{dk} 5$ in the VTA. After the behavioral tests, $(\mathrm{dk} 5$ protein levels in the VTA were determined using immunofluorescence labeling $(\boldsymbol{A}-\boldsymbol{C})$ and Western blotting $(\boldsymbol{D}, \boldsymbol{E})$. Timeline for the AAV microinjection, behavioral tests, immunofluorescence labeling, and Western blotting is shown in Figure $2 A$. $\boldsymbol{A}-\boldsymbol{C}$, Immunofluorescence labeling showed that $\mathrm{Cdk} 5$ was expressed in the VTA in Cdk5 ${ }^{\text {loxP/loxP }}$ mice that received intra-VTA injection of AAV2-GFP $(\boldsymbol{A})$ or in Cdk5 ${ }^{\text {wt/wt }}$ mice that received intra-VTA injection of AAV2-Cre-GFP (C). However, Cdk5 was lost in the VTA in Cdk5 ${ }^{\text {loxP/loxP }}$ mice that received intra-VTA injection of AAV2-Cre-GFP (B). Scale bar, $50 \mu \mathrm{m}$. D, E, Representative (D) and summarized (E) data of Western blots for $C \mathrm{dk} 5, \mathrm{p} 35 / 25$, and GAPDH showing that VTA-specific deletion of Cdk5 significantly decreased protein levels of $\mathrm{Cdk} 5$ in the VTA $(p<0.001)$ without affecting the protein levels of $\mathrm{Cdk} 5$ cofactor p35 $(p>0.05)$. Immunoreactivity was normalized to GAPDH and is presented as a percentage of that of Cdk5 ${ }^{\text {loxP/loxP }}$ mice with AAV2-GFP injection group. The $p$ values for Tukey's post hoc test results are shown on the top ( ${ }^{* * *} p<0.001 ; n=6$ mice/group).

$p=0.04$; nonstress vs sub-CUS, $p=1.00)$. In the NSF test, stress and $\mathrm{Cdk} 5 \mathrm{cKO}$ had significant main effects on the latency to feed in the novel environment (stress: $F_{(2,59)}=5.47, p=0.007$; Cdk5 cKO: $F_{(1,59)}=15.73, p<0.001$; stress $\times$ Cdk5 cKO interaction: $F_{(2,59)}=3.20, p=0.04$; Fig. $\left.5 D\right)$. Tukey's post hoc tests indicated that, in nonstressed groups, Cdk5 cKO mice showed significant increase in the latency to feed compared with wild-type control mice $(p=0.02)$. In sub-CUS groups, Cdk5 cKO mice also exhibited significant increase in the latency to feed compared with control mice $(p=0.002)$. However, CUS significantly increased the latency to feed in control mice $(p=0.001)$ but did not produce further increase in the latency to feed in Cdk5 cKO mice $(p=0.87)$. In contrast, neither stress nor C $\mathrm{dk} 5 \mathrm{cKO}$ affected the latency to feed in the home cage (stress: $F_{(2,59)}=0.45, p=0.64$; Cdk5 cKO: $F_{(1,59)}=1.21, p=0.28$; stress $\times$ Cdk5 cKO interaction: $F_{(2,59)}=0.83, p=0.44$; Fig. $\left.5 D\right)$, suggesting that changes in the latency to feed in the novel environment in the NSF test cannot be explained by possible changes in appetite. In the FST, stress and Cdk5 cKO had main effects on the immobility time (stress: $F_{(2,59)}=5.99, p=0.004$; Cdk5 cKO: $F_{(1,59)}=16.19, p<$ 0.001 ; stress $\times \mathrm{Cdk} 5 \mathrm{cKO}$ interaction: $F_{(2,59)}=3.27, p=0.04$; Fig. $5 E$ ). In nonstressed groups, $\mathrm{Cdk} 5 \mathrm{cKO}$ mice showed significant increase in the immobility time compared with wild-type control mice ( $p=0.03$ ). In sub-CUS groups, Cdk5 cKO mice also showed significant increase in the immobility time compared with control mice $(p=0.002)$, whereas CUS significantly increased the immobility time in control mice $(p=0.02)$, but did not produce further increase in the immobility time in Cdk $5 \mathrm{cKO}$ mice $(p=0.80)$. Together, these results suggest that $\mathrm{Cdk} 5 \mathrm{cKO}$ increased stress vulnerability in the SPT, but not in the FST or NSF tests.

\section{VTA- or dopamine neuron-specific deletion of Cdk5} decreased the phosphorylation of TH and CREB

To find the molecular mechanisms responsible for the depressive-like behavior induced by Cdk5 deletion, we investigated whether Cdk5 substrates were altered by Cdk5 deletion in the VTA (AAV2-Cre-GFP) or dopamine neurons (Cdk5 cKO). Cdk5 interacts with a large number of substrates (Barnett and Bibb, 2011; Su and Tsai, 2011). One of the Cdk5 substrates is TH, the rate-limiting enzyme for dopamine synthesis (Dunkley et al., 2004). Cdk5 phosphorylates TH at serine residue Ser31 (Kansy et al., 2004; Moy and Tsai, 2004), but not at Ser40 (Kansy et al., 2004). Western blotting was performed to determine p-TH at Ser31 and Ser40 and total TH in VTA tissue samples. In the first set of experiments, we examined the effects of VTA-specific deletion of Cdk5 with AAV2-Cre-GFP on $\mathrm{p}-\mathrm{TH}$ and $\mathrm{TH}$ protein levels. VTA tissue samples were prepared from Cdk $5^{\text {loxP/loxP }}$ mice that received intra-VTA injection of AAV2-Cre-GFP or AAV2GFP and from Cdk ${ }^{\mathrm{wt} / \mathrm{wt}}$ mice that received intra-VTA injection of AAV2-Cre-GFP (Fig. 6A,B). There was a significant decrease in the protein level of $\mathrm{p}-\mathrm{TH}(\mathrm{Ser} 31)$ in $\mathrm{Cdk} 5^{\text {loxP/loxP }}$ mice that received AAV2-Cre-GFP injection compared with the other two groups $\left(F_{(2,12)}=15.00, p<0.001\right)$. The phosphorylation of TH at Ser40 in the VTA was also decreased after VTA-specific deletion of Cdk5 $\left(F_{(2,12)}=9.54, p=0.003\right)$ and the total TH protein levels were not significantly changed $\left(F_{(2,12)}=0.99, p=0.40\right.$; Fig. $6 A, B)$. In the second set of experiments, we performed Western 
A

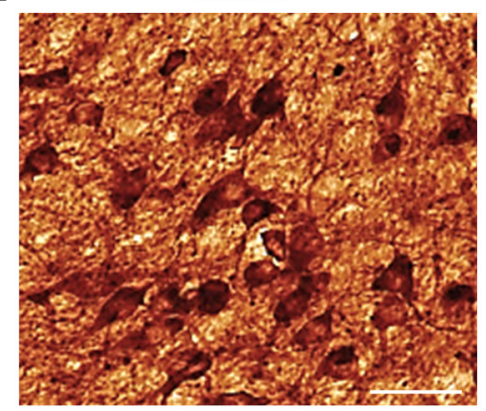

Cdk5 cKO

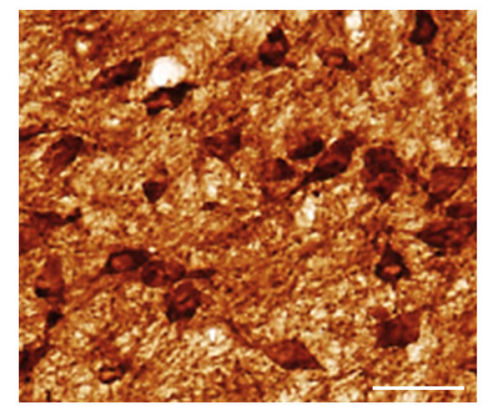

B

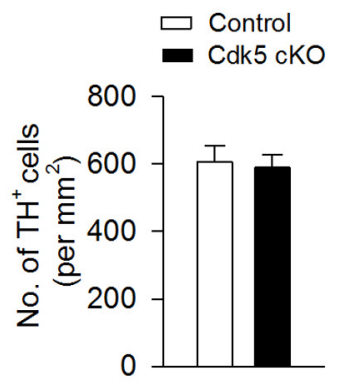

C
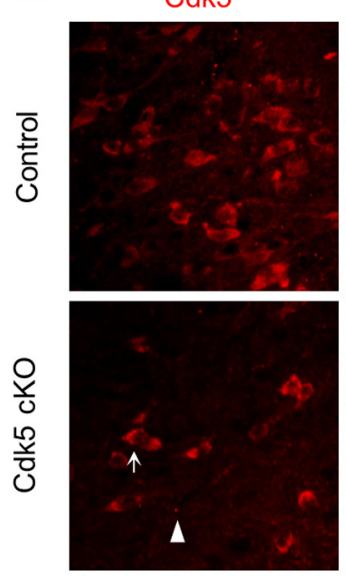

$\mathrm{TH}$
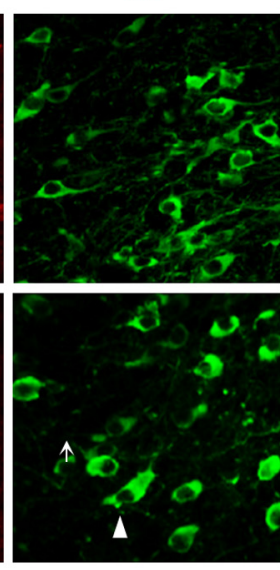

Overlay

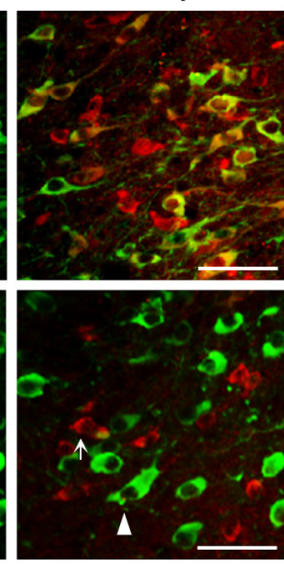

D
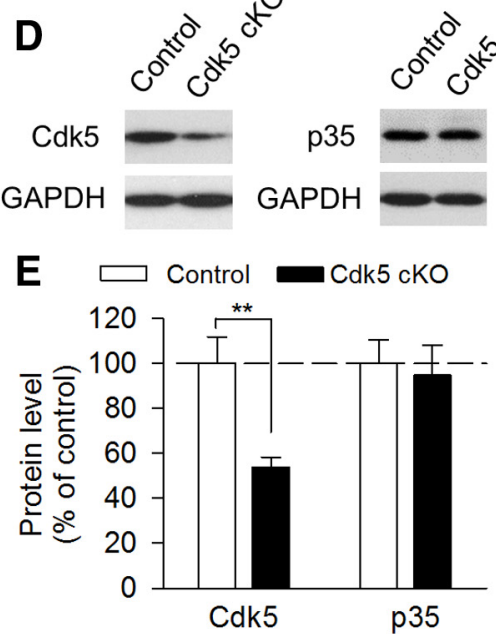

Figure 4. Generation of dopamine neuron-specific C $\mathrm{dk} 5 \mathrm{cKO}$ mice. A, DAB staining for TH of VTA sections of control and Cdk5 $\mathrm{cKO}$ mice. Scale bar, $50 \mu \mathrm{m}$. B, Summarized data showing that the total numbers of $\mathrm{TH}^{+}$dopamine neurons were not significantly different between control and Cdk5 cK0 mice ( $p>0.05 ; n=12$ sections from 3 mice/group). C, Immunofluorescence staining for Cdk5 (red) and TH (green) of VTA sections of control and Cdk5 $\mathrm{CKO}$ mice. (dk5 was expressed in both TH ${ }^{+}$and $\mathrm{TH}^{-}$neurons in the VTA in control mice (top). Cdk5 was absent in TH ${ }^{+}$dopamine neurons (indicated by arrowhead), but was expressed in $\mathrm{TH}^{-}$neurons (indicated by arrow) in (dk5 cKO mice (bottom; $n=3$ mice/group). Scale bar, $50 \mu \mathrm{m}$. $\boldsymbol{D}, \boldsymbol{E}$, Representative (D) and summarized (E) data of Western blots showing that Cdk5 levels in the VTA were significantly decreased in (dk5 cK0 mice compared with those in control mice ${ }^{* * *} p<0.01 ; n=6$ animals/group). However, $\mathrm{p} 35$ protein levels were not significantly different between these two genotypes $(p>0.05)$. Immunoreactivity was normalized to GAPDH and is presented as a percentage of that of control mice.

blotting for $\mathrm{p}-\mathrm{TH}$ at Ser31 and Ser40 and total TH in VTA tissue samples prepared from Cdk5 cKO and control mice (Fig. 6C,D). There was a significant decrease in the protein level of $\mathrm{p}-\mathrm{TH}$ (Ser31) in Cdk5 cKO mice compared with that of control mice $\left(t_{(10)}=2.37, p=0.04\right) \cdot \mathrm{p}-\mathrm{TH}$ (Ser40) levels in the VTA was also decreased in Cdk5 cKO mice $\left(t_{(10)}=2.39, p=0.04\right)$. Cdk $5 \mathrm{cKO}$ had a modest effect on the total TH protein level that did not reach statistical significance $\left(t_{(10)}=1.27, p=0.23\right.$; Fig. $\left.6 C, D\right)$.

What might be the mechanism for Cdk5 deletion-induced decrease in p-TH (Ser40) levels? TH phosphorylation at Ser40 is known to be controlled by PKA (Haycock, 1996; Salvatore et al., 2001; Kansy et al., 2004). We measured cAMP levels in VTA tissue samples using an ELISA. We found that cAMP levels were significantly decreased in $\mathrm{Cdk} 5^{\text {loxP/loxP }}$ mice that received AAV2Cre-GFP injection compared with those in $\mathrm{Cdk} 5^{\text {loxP/loxP }}$ mice that received AAV2-GFP injection or $\mathrm{Cdk} 5^{\mathrm{wt} / \mathrm{wt}}$ mice that received AAV2-Cre-GFP injection $\left(F_{(2,12)}=7.20, p=0.009\right.$; Fig. $7 A$ ). Similarly, cAMP levels were also significantly decreased in Cdk5 $\mathrm{cKO}$ mice compared with those in control mice $\left(t_{(10)}=\right.$ 3.59, $p=0.005$; Fig. $7 B$ ). cAMP/PKA phosphorylates and activates the transcription factor CREB at Ser133 (Silva et al., 1998). CREB in the NAc has been linked to mood regulation (Park et al., 2005; Wallace et al., 2009). Western blotting analysis showed that p-CREB (Ser 133) in the VTA was significantly decreased in Cdk5 cKO mice $\left(t_{(12)}=3.34, p=0.006\right.$; Fig. $\left.7 C, D\right)$. In addition, im- munohistochemical staining of midbrain VTA sections with p-CREB showed that $\mathrm{p}-C R E B^{+}$cells in the VTA were significantly decreased in Cdk5 cKO mice $\left(t_{(30)}=5.48, p<0.001\right.$; Fig. $7 E, F)$.

\section{Cdk5 cKO decreased dopamine responses in the NAc}

Phosphorylation of TH at Ser40 increases the catalytic activity of $\mathrm{TH}$, and thereby dopamine synthesis, and phosphorylation of TH at Ser31 also increases the catalytic activity of TH, but to a much less extent than for Ser40 phosphorylation (Dunkley et al., 2004). The decreases in p-TH at Ser31 and Ser40 imply that dopamine synthesis and release was decreased in Cdk5 cKO mice. To test this, we measured dopamine concentration in the shell of NAc slices directly using FSCV (Wightman, 2006; Yorgason et al., 2011). Dopamine is synthesized by dopamine neurons in the VTA and is axonally transported for release in the NAc. Dopamine release was evoked by electrical stimulation and detected by carbon-fiber microelectrode placed in the NAc shell. We examined dopamine responses evoked by a single electrical stimulus pulse or a train of stimuli (5 pulses) at 10,30 , and $50 \mathrm{~Hz}$ at fixed intensity (250 $\mu \mathrm{A}, 0.1 \mathrm{~ms}$ duration; Fig. 8$)$. The recordings were made with the investigator blinded to the genotypes of the mice. The average peak concentration of dopamine in the NAc shell was decreased in Cdk5 cKO mice at single pulse and 10, 30, and 50 $\mathrm{Hz}$ 5-pulse stimulation (1 pulse: $t_{(25)}=2.26, p=0.03 ; 10 \mathrm{~Hz}$ : 
A

sub-CUS: 1 week

CUS: 5 weeks

$\square$ Control

- Cdk5 cKO

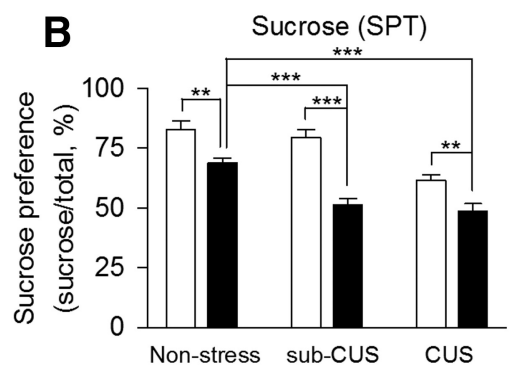

Novelty-suppressed feeding (NSF)

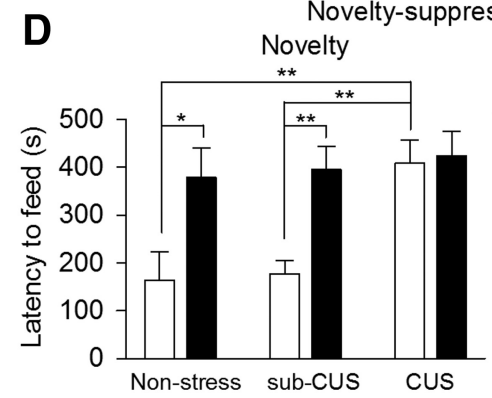

Open field test (OFT)
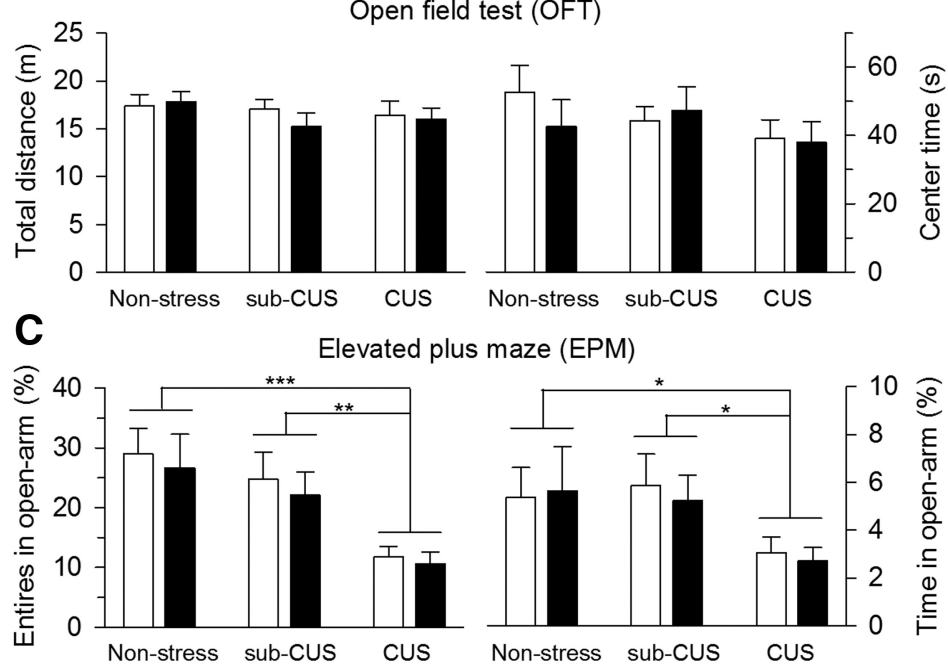

E

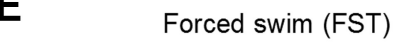

Figure 5. C C $\mathrm{dk} 5 \mathrm{cK} 0$ mice exhibited anxiety- and depressive-like behaviors. Control and $\mathrm{Cdk} 5 \mathrm{cK} 0$ mice were subjected to various and repeated unpredictable mild stressors for a period of 1 week (sub-CUS) or 5 weeks (CUS) or were not subjected to any stressors (nonstressed). $A$, In the OFT neither stress nor Cdk5 cK0 altered the total distance traveled $(p>0.05)$ or center time $(p>0.05)$. $B$, In nonstressed groups, Cdk5 cK0 mice showed significant decrease in the SPT compared with wild-type control mice (** $p<0.01)$. In sub-CUS groups, Cdk5 cK0 mice exhibited significant decrease in the SPT compared with control mice $\left({ }^{* * *} p<0.001\right)$. In the CUS groups, Cdk5 cKO mice showed significant decrease in the sucrose preference compared with wild-type control mice $\left({ }^{* *} p<0.01\right)$. CUS $\left({ }^{* * *} p<0.001\right)$, but not sub-CUS $(p>0.05)$, significantly decreased sucrose preference in wild-type control mice. However, both sub-CUS $\left({ }^{* * *} p<0.001\right)$ and CUS $(* * * p<0.001)$ further decreased sucrose preference in Cdk5 CKO mice. C, In the EPM test, CUS, but not sub-CUS, significantly decreased the number of entries in the open arms (nonstress vs CUS, ${ }^{* * *} p<0.001$; sub-CUS vs CUS, ${ }^{* *} p<0.01$ ) and the time spent in the open arms (nonstress vs CUS, ${ }^{*} p<0.05$; sub-CUS vs CUS, ${ }^{*} p<0.05$ ). However, Cdk5 cK0 had no significant effects on the number of entries into the open arms $(p>0.05)$ and the time spent in the open arms $(p>0.05)$. $\boldsymbol{D}$, In nonstressed groups, Cdk5 cK0 mice showed a significant increase in the latency to feed in the novel environment compared with wild-type control mice $\left.{ }^{*} p<0.05\right)$. In the sub-CUS groups, Cdk5 cK0 mice also showed significant increase in the latency to feed compared with control mice $\left.{ }^{* *} p<0.01\right)$, whereas CUS significantly increased the latency to feed in control mice $\left.{ }^{* *} p<0.01\right)$, but did not produce further increases in the latency to feed in Cdk5 cK0 mice $(p>0.05)$ in the NSF test. Neither stress $(p>0.05)$ nor Cdk5 cKO ( $p>0.05)$ affected the latency to feed in the home cage. $\boldsymbol{E}$, In nonstressed groups, Cdk5 cK0 mice showed significant increase in the immobility time compared with wild-type control mice $\left({ }^{*} p<0.05\right)$. In the sub-CUS groups, Cdk5 cK0 mice also showed significant increases in immobility time compared with control mice $\left({ }^{* *} p<0.01\right)$, whereas (US significantly increased immobility time in control mice $\left.{ }^{*} p<0.05\right)$ but did not produce further increases in immobility time in Cdk5 CK0 mice $(p>0.05)$. The $p$ values for Tukey's post hoc test results are shown on the top $\left({ }^{*} p<0.05,{ }^{* *} p<0.01 ;{ }^{* * *} p<0.001 ; n=10-12\right.$ mice/group).

$t_{(25)}=3.62, p=0.001 ; 30 \mathrm{~Hz}: t_{(25)}=3.31, p=0.003 ; 50 \mathrm{~Hz}: t_{(25)}$ $=2.56, p=0.02$; Fig. $8 B$ ). The decay time constant $(\tau)$ of falling phase of dopamine transients is a function of dopamine uptake rate (Yorgason et al., 2011). The decay time constants of the dopamine responses were not significantly different between control and Cdk5 cKO mice at all stimulation frequencies (1 pulse: $t_{25}=0.66, p=0.51 ; 10 \mathrm{~Hz}: t_{25}=1.01, p=0.32 ; 30 \mathrm{~Hz}: t_{25}$ $=0.67, p=0.51 ; 50 \mathrm{~Hz}: t_{25}=0.17, p=0.86$; Fig. $8 C$ ), suggesting that dopamine clearance in the NAc is not altered by Cdk $5 \mathrm{cKO}$. Together, these results suggest that $\mathrm{Cdk} 5 \mathrm{cKO}$ in dopamine neurons decreased the phosphorylation of $\mathrm{TH}$ (Ser31) and $\mathrm{TH}$ (Ser40), which in turn decreased dopamine synthesis in the VTA and dopamine release in its target region, the NAc.

It has been shown that bath application of the Cdk5 inhibitor roscovitine enhanced dopamine response in striatal slices, as detected by amperometry (Chergui et al., 2004). Cdk5 inhibitors may increase dopamine responses by enhancing P/Q-type calcium channels (Tomizawa et al., 2002; Yan et al., 2002) and presynaptic neurotransmitter release (Kim and Ryan, 2010).
Moreover, roscovitine inhibits dopamine transporter activity directly and independently of Cdk5 (Price et al., 2009) and dopamine uptake inhibitors are known to enhance dopamine response in the striatum (Yorgason et al., 2011).

\section{Selective elevation of cAMP levels in VTA dopamine neurons} reversed depressive-like behaviors induced by Cdk5 cKO

If a decrease in cAMP signaling contributes to depressive-like behaviors induced by Cdk $5 \mathrm{cKO}$, activation of cAMP signaling in dopamine neurons should rescue these behavioral deficits. We used the Designer Receptors Exclusively Activated by Designer Drugs (DREADD) technology to selectively elevate cAMP levels in VTA dopamine neurons and examined its impact on depression-related behaviors. DREADDs are mutated muscarinic G-protein-coupled receptors that are exclusively activated by pharmacologically inert ligand $\mathrm{CNO}$, but not natural neurotransmitters (Armbruster et al., 2007). By expressing Gscoupled DREADD (rM3D-Gs; Guettier et al., 2009; Farrell et al., 2013) selectively in dopamine neurons in the VTA, one can in- 
ducibly and reversibly increase cAMP levels in the VTA with cell specificity. Creinducible AAVs carrying a "doublefloxed" inverted open reading frame (AAV8-hSyn-DIO-rM3D-Gs-mCherry, referred as rM3D-Gs) were bilaterally microinjected into the VTA of Cdk $5 \mathrm{cKO}$ and control mice. Three weeks after the AAV injections, we examined the expression of the AAVs in midbrain sections. In $\mathrm{Cdk} 5 \mathrm{cKO}$ mice, the AAVs, as indicated by mCherry, were expressed in $\sim 85 \%$ of $\mathrm{TH}^{+}$dopamine neurons (green), but were not expressed in $\mathrm{TH}^{-}$neurons in the VTA. The AAVs were largely limited to VTA and were seldom expressed in the neighboring substantia nigra (Fig. 9). In

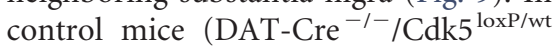
or DAT-Cre $\left.{ }^{-l-} / \mathrm{Cdk} 5^{\text {loxP/loxP }}\right)$, the AAVs (mCherry) were not expressed because of the lack of Cre-recombinase in these mice (data not shown).

Having confirmed the expression of rM3D-Gs in VTA dopamine neurons, we next examined the effectiveness of intraperitoneal injection of $\mathrm{CNO}$ in activating rM3D-Gs in the VTA. The timeline of the AAV injection, ELISA, Western blotting, and FSCV is shown in Figure 10A. Previous studies have shown that intraperitoneal injection of CNO rapidly ( $<15 \mathrm{~min}$ ) activates DREADDs in the brain, reaches the peak after $\sim 30-40 \mathrm{~min}$, and the effect of CNO lasts several hours (Alexander et al., 2009; Rogan and Roth, 2011). We therefore chose to inject saline $(0.9 \% \mathrm{NaCl})$ or $\mathrm{CNO}(2 \mathrm{mg} / \mathrm{kg}$ in saline) $30 \mathrm{~min}$ before euthanizing the mice and collecting VTA tissue samples. We measured cAMP levels in VTA samples using ELISA. Two-way ANOVA analysis revealed that CNO injection, but not genotype, had significant main effects on cAMP levels in the VTA (genotype: $F_{(1,21)}=1.66, p=0.21$; CNO: $F_{(1,21)}=17.56$, $p<0.001$; genotype $\times \mathrm{CNO}$ interaction: $F_{(1,21)}=19.96, p<$ 0.001 ; Fig. 10B). Tukey's post hoc tests showed that cAMP levels in the VTA were significantly decreased in $\mathrm{Cdk} 5 \mathrm{cKO}$ mice compared with control mice ( $p=0.039)$, CNO did not cause cAMP accumulation in control mice that did not express rM3D-Gs due to lack of Cre-recombinase, but greatly enhanced cAMP levels in Cdk5 cKO mice that expressed rM3D-Gs selectively in dopamine neurons $(p<0.001)$.

We therefore investigated whether CNO increased $\mathrm{p}$-CREB (Ser133), p-TH (Ser40), and p-TH (Ser31) in the VTA. Two-way ANOVA analysis revealed that $\mathrm{Cdk} 5 \mathrm{cKO}$ and $\mathrm{CNO}$ injection had significant main effects on p-CREB (Ser133; Cdk5 cKO: $F_{(1,16)}=$ 17.03, $p<0.001$; CNO: $F_{(1,16)}=4.58, p=0.04$; Cdk5 cKO $\times$ CNO interaction: $F_{(1,16)}=6.69, p=0.02$; Fig. $\left.10 C, D\right)$ and $\mathrm{p}-\mathrm{TH}$ (Ser40) levels (Cdk5 cKO: $F_{(1,16)}=12.97, p=0.002$; CNO: $F_{(1,16)}$ $=7.21, p=0.02$; Cdk5 $\mathrm{cKO} \times \mathrm{CNO}$ interaction: $F_{(1,16)}=4.54$, $p=0.04$; Fig. 10C,E) in the VTA. Tukey's post hoc tests showed that the levels of p-CREB (Ser133) and p-TH (Ser40) were significantly decreased in Cdk5 cKO mice compared with those in control mice (p-CREB: $p<0.001$; $\mathrm{p}$-TH: $p=0.001$ ), and these decreases were reversed by CNO ( $\mathrm{p}$-CREB: $p=0.004$; $\mathrm{p}-\mathrm{TH}: p=$ 0.004). Importantly, p-CREB (Ser133) and p-TH (Ser40) levels were not significantly different between control and Cdk5 $\mathrm{cKO}$ mice that received CNO injections ( $\mathrm{p}$-CREB: $p=0.29$; $\mathrm{p}-\mathrm{TH}: p=$ $0.31)$. In contrast, Cdk5 cKO decreased p-TH (Ser31) levels in the VTA $\left(F_{(1,16)}=54.22, p<0.001\right)$, but CNO did not affect $\mathrm{p}-\mathrm{TH}$ (Ser31) levels $\left(F_{(1,16)}=0.11, p=0.75\right.$; Fig. 10C,F). These results suggest that activation of $\mathrm{rM} 3 \mathrm{D}-\mathrm{G}$ s by CNO increases cAMP levels and rescues Cdk5 cKO-induced deficits in CREB phosphorylation at Ser133 and TH phosphorylation at Ser40.

To determine whether changes in $\mathrm{p}-\mathrm{TH}$ (Ser40) by CNO affected dopamine release, we measured dopamine concentration directly in the shell of NAc slices prepared from these 4 groups of mice $30 \mathrm{~min}$ after intraperitoneal injections of saline or CNO $(2$ $\mathrm{mg} / \mathrm{kg}$ ). We examined dopamine responses evoked by 5 pulses at $30 \mathrm{~Hz}$, which is known to induce maximal or near maximal dopamine release in the NAc (Fig. 8). Two-way ANOVA revealed that $\mathrm{Cdk} 5 \mathrm{cKO}$ and $\mathrm{CNO}$ injection had significant main effects on dopamine concentration in the NAc (Cdk5 cKO: $F_{(1,38)}=26.54$, $p<0.001$; CNO: $F_{(1,38)}=5.01, p=0.03$; Cdk5 cKO $\times \mathrm{CNO}$ interaction: $F_{(1,38)}=12.56, p=0.001$; Fig. $\left.10 G, H\right)$. Tukey's post hoc tests showed that the dopamine concentration was significantly decreased in Cdk5 cKO mice compared with those in control mice $(p<0.001)$ and these decreases were reversed by $\mathrm{CNO}$ $(p<0.001)$.

We next determined whether activation of rM3D-Gs by CNO in VTA dopamine neurons could rescue depressive-like behaviors induced by Cdk5 cKO. Control (DAT-Cre ${ }^{-/-} / \mathrm{Cdk} 5^{\text {loxP/loxP }}$ or DAT-Cre $\left.{ }^{-/-} / \mathrm{Cdk}^{\text {loxP/wt }}\right)$ and Cdk5 cKO (DAT-Cre ${ }^{+/-} /$ $\mathrm{Cdk} 5^{\text {loxP/loxP }}$ mice received bilateral intra-VTA injections of 


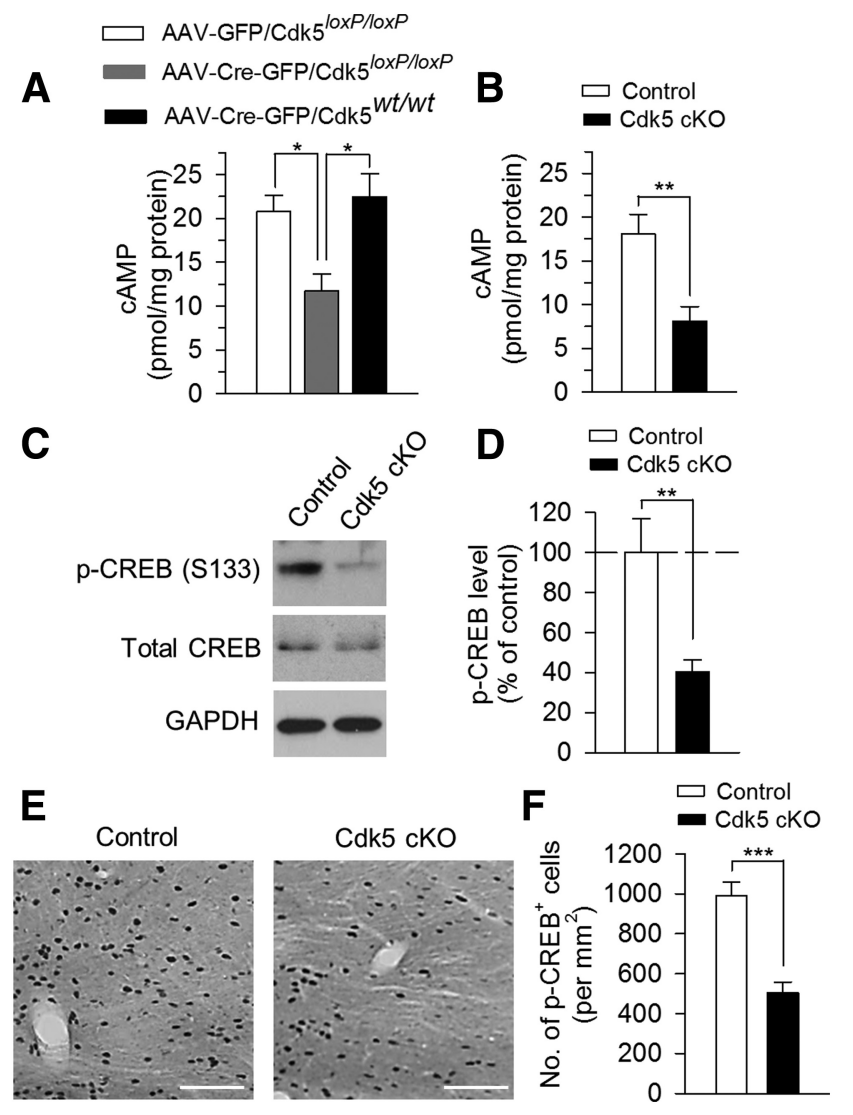

Figure 7. VTA- or dopamine neuron-specific deletion of Cdk5 disrupted CAMP signaling in the VTA. $\boldsymbol{A}$, ELISA showing that CAMP levels were significantly decreased in Cdk5 ${ }^{\text {loxP/loxP }}$ mice that received AAV2-Cre-GFP injection compared with those in Cdk5 ${ }^{\text {loxP/loxP }}$ mice that received AAV2-GFP injection or Cdk5 ${ }^{\mathrm{wt} / \mathrm{wt}}$ mice that received AAV2-Cre-GFP injection $(p<0.01)$. The $p$ values for Tukey's post hoc test results are shown on the top ( ${ }^{*} p<0.05 ; n=5$ mice/group). $\boldsymbol{B}$, ELISA showing that CAMP levels in the VTA were significantly decreased in Cdk5 CKO mice compared with those in control mice $\left({ }^{*} p<0.01 ; n=6\right.$ mice/group). $\boldsymbol{C}, \boldsymbol{D}$, Representative $(\boldsymbol{C})$ and summarized (D) data of Western blots showing that $\mathrm{p}$-CREB (Ser133) levels in the VTA were significantly decreased in Cdk5 CKO mice compared with those in control mice ${ }^{* *} p<0.01 ; n=$ 7 mice/group). Immunoreactivity was normalized to GAPDH and is presented as a percentage of that of control mice. $\boldsymbol{E}, \boldsymbol{F}$, Representative $(\boldsymbol{E})$ and summarized $(\boldsymbol{F})$ data of DAB staining showing that p-CREB ${ }^{+}$cells in the VTA were significantly decreased in Cdk5 cKO mice compared with those in control mice ${ }^{* * *} p<0.001 ; n=16$ sections from 4 mice/group). Scale bar, $100 \mu \mathrm{m}$.

rM3D-Gs as shown in Figure 10. We added an additional control group (DAT-Cre ${ }^{+/-} / \mathrm{Cdk} 5^{\mathrm{wt} / \mathrm{wt}}$ ) of mice that received bilateral intra-VTA injections of rM3D-Gs. The timeline of the AAV injection and behavioral tests is shown in Figure 11A. Three weeks after the AAV injections, mice received intraperitoneal injection of saline or CNO (2 mg/kg) $30 \mathrm{~min}$ before each of the behavioral tests except for the SPT, during which mice received CNO injection every $8 \mathrm{~h} 2$ times because the behavioral effects of $\mathrm{CNO}$ persist for several hours (Alexander et al., 2009). In the OFT 2-way ANOVA showed that genotype and CNO injection had significant main effects on locomotor activity, as indicated by the total traveled distance (genotype: $F_{(2,49)}=11.44, p<0.001$; CNO: $F_{(1,49)}=10.82, p=0.002$; genotype $\times$ CNO interaction: $F_{(2,49)}=3.25, p=0.04$; Fig. $\left.11 B\right)$. Tukey's post hoc tests showed that $\mathrm{CNO}$ injection, but not saline injection, increased locomotor activity in Cdk5 cKO $(p=0.006)$ and DAT-Cre ${ }^{+/-} / \mathrm{Cdk} 5^{\mathrm{wt} / \mathrm{wt}}$ $(p=0.004)$ mice without affecting the locomotor activity in control mice that did not express rM3D-Gs $(p=0.85)$. Neither genotype nor $\mathrm{CNO}$ injection had significant effects on the center time in the open field (genotype: $F_{(2,49)}=0.87, p=0.43$; CNO:
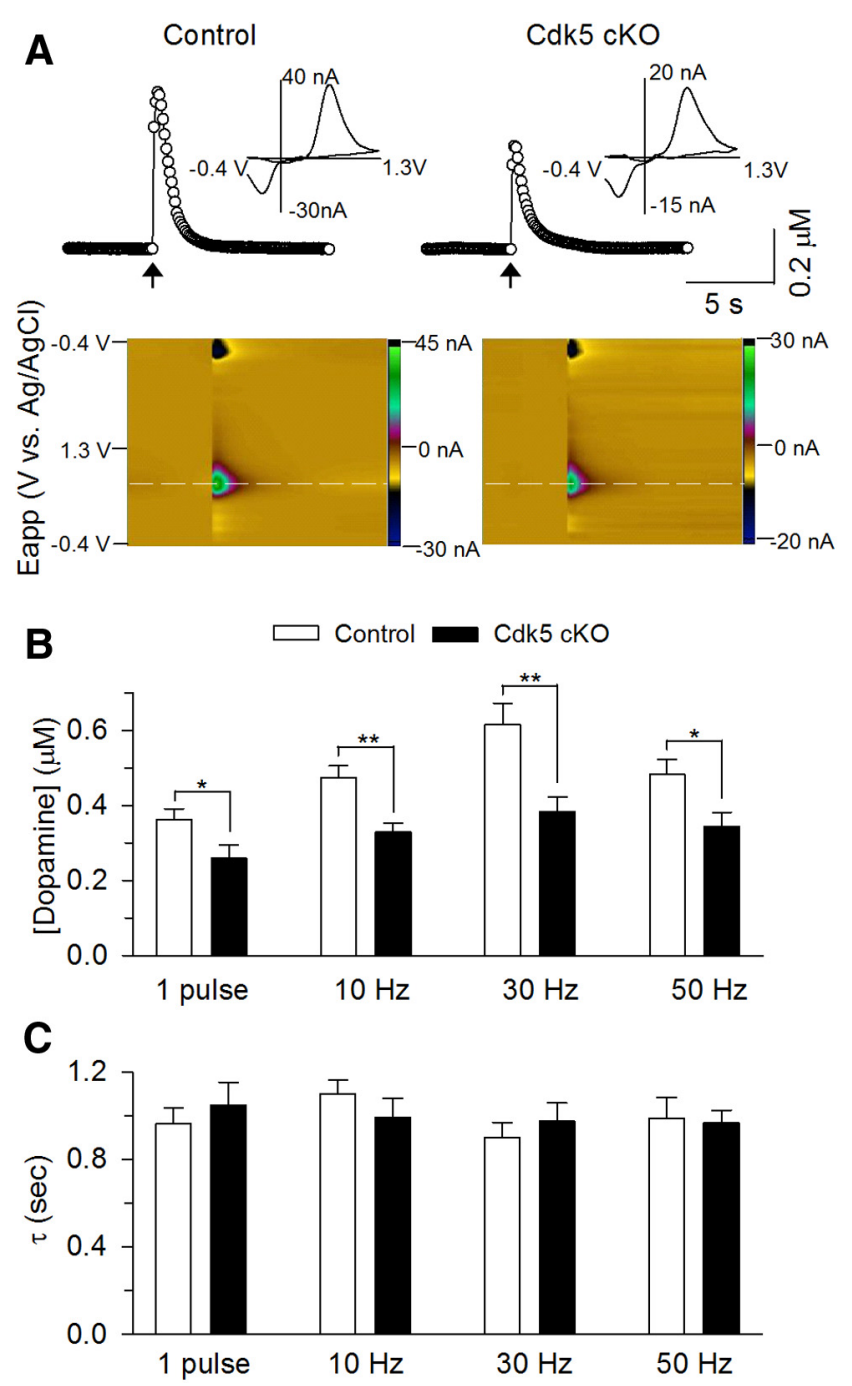

Figure 8. Cdk5 CKO decreased dopamine release in the NAc shell. $\boldsymbol{A}$, Concentration trace (top) and color plot (bottom) for dopamine release triggered by electrical stimulation of the NAC shell in control and Cdk5 cKO mice. Top, Representative traces showing the concentration of dopamine $(\mu \mathrm{m})$ over time in response to 5 -pulse electrical stimulation at $30 \mathrm{~Hz}$ (indicated by arrow). Inset shows characteristic dopamine voltammogram. Bottom, Corresponding color plot depicting the voltammetric data with time on the $x$-axis, applied scan potential (Eapp) on the $y$-axis, and background-subtracted faradaic current shown on the z-axis in pseudocolor. Dopamine can be identified by an oxidation peak (green) at $+0.6 \mathrm{~V}$ and a smaller reduction peak (black) at -0.2 V. $\boldsymbol{B}$, Summarized data showeingthe average peak concentration of dopamine in the NAc Shell in response to single pulse and 5 -pulse stimulation $(10,30$, and $50 \mathrm{~Hz}$; indicated by arrow). Dopamine release was significantly decreased in (dk5 cK0 mice at single pulse $\left({ }^{*} p<\right.$ $0.05), 10 \mathrm{~Hz}\left({ }^{* *} p<0.01\right), 30 \mathrm{~Hz}\left({ }^{* *} p<0.01\right)$, and $50 \mathrm{~Hz}\left({ }^{*} p<0.05\right)$ stimulation compared with those in control mice. $C$, Summarized data showing no difference in the decay time constant $(\tau)$ of the dopamine responses between control and Cdk5 CKO mice at all stimulation frequencies ( $p>0.05 ; n=14$ from 5 control mice; $n=13$ from 5 (dk5 cK0 mice).

$F_{(1,49)}=0.88, p=0.35$; genotype $\times \mathrm{CNO}$ interaction: $F_{(2,49)}=$ $1.05, p=0.36$; Fig. $11 B$ ). In the SPT, genotype and CNO injection had main effects on the sucrose preference (genotype: $F_{(2,49)}=$ 15.17, $p<0.001$; CNO: $F_{(1,49)}=8.01, p=0.007$; genotype $\times$ CNO interaction: $F_{(2,49)}=3.21, p=0.04$; Fig. 11C). Tukey's post hoc tests showed that the sucrose preference was significantly decreased in Cdk5 cKO mice compared with control $(p<0.001)$ and DAT-Cre ${ }^{+/-} / \mathrm{Cdk} 5^{\mathrm{wt} / \mathrm{wt}}(p<0.001)$ mice, and this decrease was reversed by CNO injection $(p=0.004)$. In addition, $\mathrm{CNO}$ injection did not significantly affect sucrose preference in DAT$\mathrm{Cre}^{+/-} / \mathrm{Cdk} 5^{\mathrm{wt} / \mathrm{wt}}$ mice $(p=0.28)$. In the EPM test, neither ge- 
A

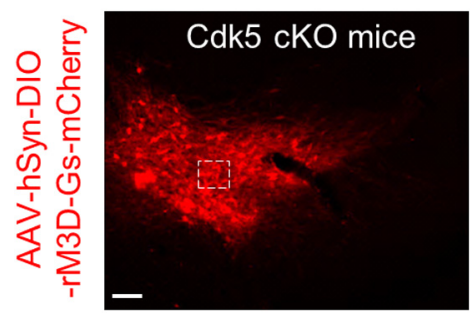

B
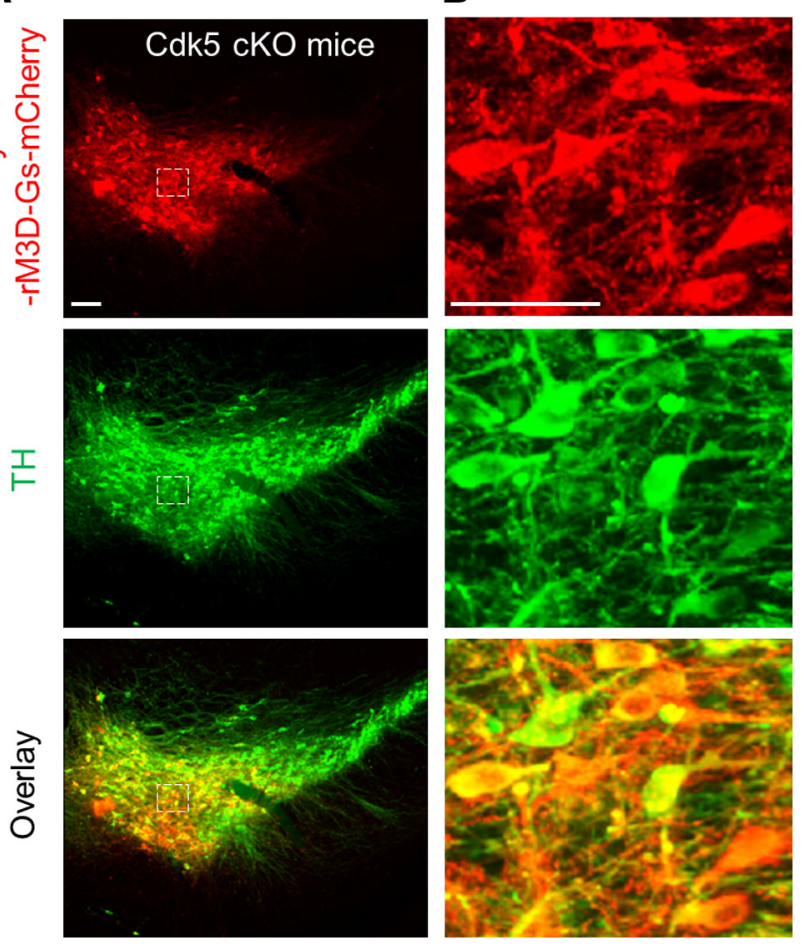

Figure 9. The DREADD receptor $r M 3 D-G s$ was expressed in midbrain dopamine neurons in the $\mathrm{Cdk} 5 \mathrm{cKO}$ (DAT-Cre ${ }^{+/-} / \mathrm{Cdk}^{\text {loxP/loxP }}$ ) mice. $A$, Immunofluorescence labeling for AAV8hSyn-DI0-rM3D-Gs-mCherry (red) and TH (green) in the midbrain VTA sections. Scale bar, 100 $\mu \mathrm{m} . \boldsymbol{B}$, High-power view of AAV8-hSyn-DI0-rM3D-Gs-mCherry and TH staining in the dashed boxes shown in $\boldsymbol{A}$. AAVs were expressed in $\sim 85 \%$ of VTA dopamine neurons in the VTA. Scale bar, $50 \mu \mathrm{m} . n=3$ mice/group.

notype nor $\mathrm{CNO}$ injection had significant effects on the number of entries into the open arms (genotype: $F_{(2,49)}=0.57, p=0.57$; CNO: $F_{(1,49)}=0.01, p=0.90$; genotype $\times$ CNO interaction: $\left.F_{(2,49)}=0.45, p=0.64\right)$ and the time spent in the open arms (genotype: $F_{(2,49)}=0.73, p=0.49 ; \mathrm{CNO}: F_{(1,49)}=0.31, p=0.58$; genotype $\times$ CNO interaction: $F_{(2,49)}=0.66, p=0.52$; Fig. $\left.11 D\right)$. In the NSF test, genotype and CNO injection had main effects on the latency to feed in the novel environment (genotype: $F_{(2,49)}=$ $3.26, p=0.04$; CNO: $F_{(1,49)}=18.68, p<0.001$; genotype $\times \mathrm{CNO}$ interaction: $F_{(2,49)}=10.41, p<0.001$; Fig. $\left.11 E\right)$. Tukey's post hoc tests showed that the latency to feed was significantly increased in Cdk5 cKO mice compared with that in control $(p<0.001)$ and DAT-Cre ${ }^{+/-} / \mathrm{Cdk} 5^{\mathrm{wt} / \mathrm{wt}}(p<0.001)$ mice, and this increase was reversed by CNO injection $(p<0.001)$. Furthermore, CNO injection did not significantly affect the latency to feed in DAT$\mathrm{Cre}^{+/-} / \mathrm{Cdk} 5^{\mathrm{wt} / \mathrm{wt}}$ mice $(p=0.36)$. In contrast, neither genotype nor CNO injection affected the latency to feed in the home cage (genotype: $F_{(2,49)}=1.11, p=0.34$; CNO: $F_{(1,49)}=1.12, p=0.30$; genotype $\times$ CNO interaction: $F_{(2,49)}=1.63, p=0.21$; Fig. $\left.11 E\right)$. In the FST, genotype and CNO injection had main effects on the immobility time (genotype: $F_{(2,49)}=15.39, p<0.001$; CNO: $F_{(1,49)}=14.98, p<0.001$; genotype $\times$ CNO interaction: $F_{(2,49)}=$ $4.19, p=0.02$; Fig. $11 F)$. Tukey's post hoc tests showed that the immobility time was significantly increased in Cdk5 cKO mice compared with that in control $(p=0.02)$ and DAT-Cre ${ }^{+/-} /$ $\mathrm{Cdk} 5^{\mathrm{wt} / \mathrm{wt}}(p=0.002)$ mice, and CNO treatment reversed Cdk5 $c K O-i n d u c e d$ increase in the immobility time $(p=0.002)$. However, $\mathrm{CNO}$ did significantly decrease the immobility time in DAT-Cre ${ }^{+/-} / \mathrm{Cdk} 5^{\mathrm{wt} / \mathrm{wt}}$ mice $(p<0.001)$. Because CNO increased the locomotor activity in the OFT (Fig. 11B), the decrease in the immobility time in the FST might be explained by the secondary effect of increased locomotor activity. Therefore, activating rM3D-Gs in VTA dopamine neurons by CNO reversed Cdk5 cKO-induced behavioral deficits in the SPT and NSF tests and CNO decreased the immobility time in the FST in wild-type DAT-Cre ${ }^{+/-} / \mathrm{Cdk} 5^{\mathrm{wt} / \mathrm{wt}}$ mice and Cdk5 cKO (DAT-Cre ${ }^{+/-} /$ $\left.\mathrm{Cdk} 5^{\text {loxP/loxP }}\right)$ mice.

\section{Discussion}

We showed that Cdk5 deletion in the VTA and in midbrain dopamine neurons induced depressive-like behaviors that were accompanied by decreases in TH phosphorylation at Ser31 and Ser40 in the VTA and dopamine release in the NAc. Cdk5 deletion in the VTA decreased cAMP levels in the VTA, and selectively increased cAMP in VTA dopamine neurons with DREADD technology reversed Cdk5-deletion-induced deficits in TH phosphorylation, dopamine release, and depressive-like behaviors.

We used AAV-Cre-GFP and DAT-Cre driver to delete Cdk5 in $\mathrm{Cdk} 5^{\text {loxP/loxP }}$ mice. The AAV-Cre-GFP approach minimized potential effects of $\mathrm{Cdk} 5$ deletion on neuronal development. However, this approach could not discriminate between dopamine and nondopamine neurons. The $\mathrm{Cdk} 5 \mathrm{cKO}$ mice allowed us to delete Cdk5 selectively in dopamine neurons. Cdk5 deletion using these two approaches produced very similar depressionrelated behavioral phenotypes, although subtle difference in the OFT was found: mice in which Cdk5 was deleted by AAV2-CreGFP exhibited a significant decrease in the center time (Fig. 2B), whereas Cdk5 cKO mice displayed normal center time (Fig. $5 A$ ). It is unclear whether this difference can be attributed to different methods of obtaining Cdk5 deletion. We subjected control and $\mathrm{Cdk} 5 \mathrm{cKO}$ to the CUS paradigm and found that $\mathrm{Cdk} 5 \mathrm{cKO}$ mice exhibited increased stress vulnerability in the SPT, but not in the FST or NSF test (Fig. 5). Therefore, Cdk5 cKO mice exhibited increased level of anhedonia in response to chronic stress, a common feature for depression. Together, these two approaches complemented each other and provided evidence that Cdk5 activity in VTA dopamine neurons modulates depression-related behaviors. However, there are a number of important caveats and limitations to consider when interpreting the behavioral results. As discussed in a recent review (Nestler and Hyman, 2010), the FST is not a behavioral model for depression, but rather a method for screening antidepressant; sucrose preference is a good measure of anhedonia, but anhedonia is not unique to depression and is observed in other psychiatric diseases; and the NSF test may represent a better model of anxiety than depression.

Recent studies have shown that Cdk5 activity in the hippocampus regulates anxiety- and depressive-like behavior. Microinjection of a Cdk5 inhibitor into the dentate gyrus of rat hippocampus blocked depressive-like behavior induced by chronic mild stress, whereas overexpression of $\mathrm{p} 35$, an activator of $\mathrm{Cdk} 5$, in the dentate gyrus blocked the behavioral effect of certain antidepressants (Zhu et al., 2012). Mice with forebrain-specific deletion of Cdk5 in pyramidal neurons exhibit hyperactivity and increased center time in the OFT increased exploration in the light chamber in the light/dark exploration test, and decreased immobility time in the FST, suggesting reduced anxiety and depression (Su et al., 2013). Species and regional differences might explain the differential modulation of depression-related behaviors by $\mathrm{Cdk} 5$ deletion in the hippocampus and VTA.

$\mathrm{TH}$, the rate-limiting enzyme in dopamine synthesis, is a known Cdk5 substrate (Kansy et al., 2004; Moy and Tsai, 2004). Cdk5 phosphorylates TH at Ser31 (Kansy et al., 2004; Moy and Tsai, 2004), but not at Ser40 (Kansy et al., 2004). We found that 
A
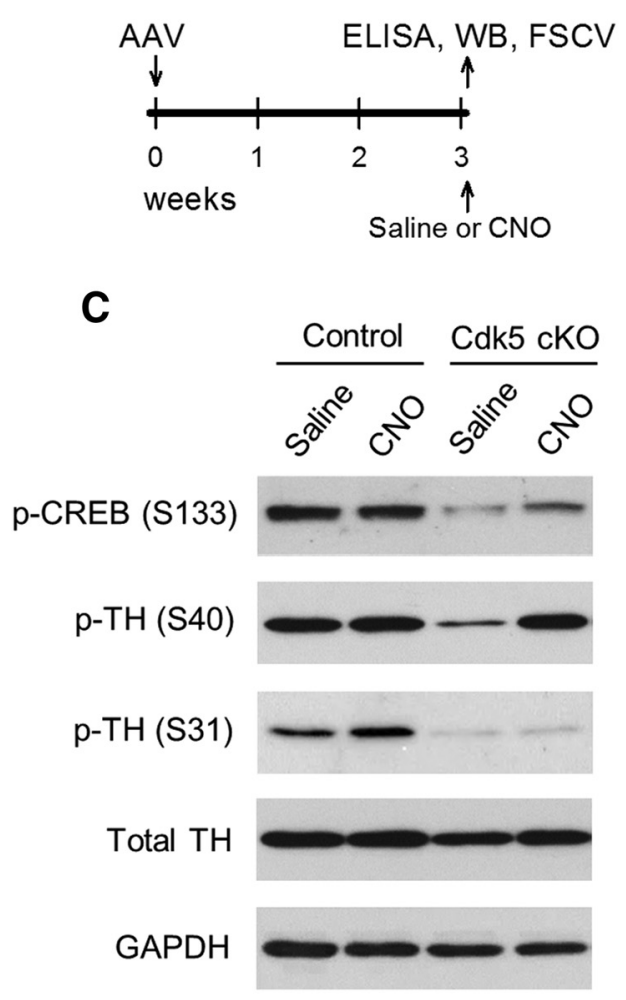

B

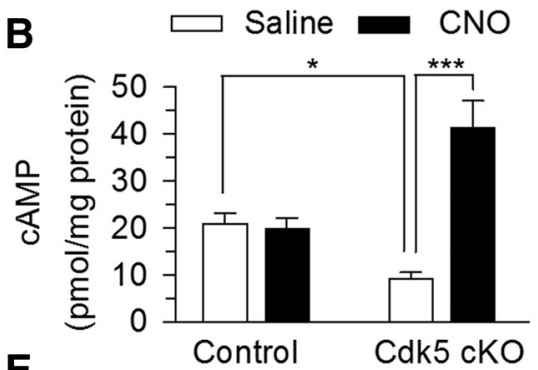

E

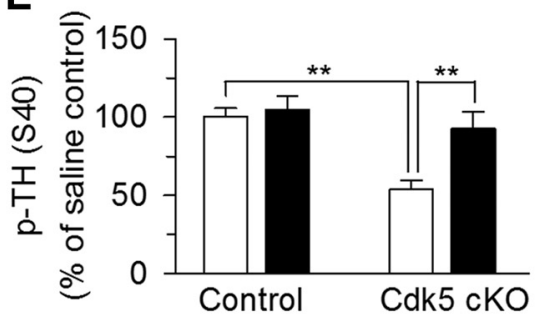

Control

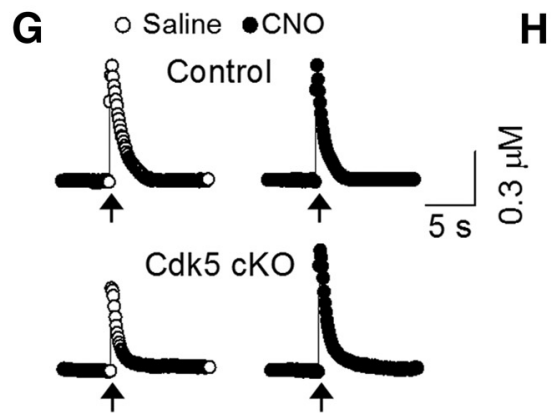

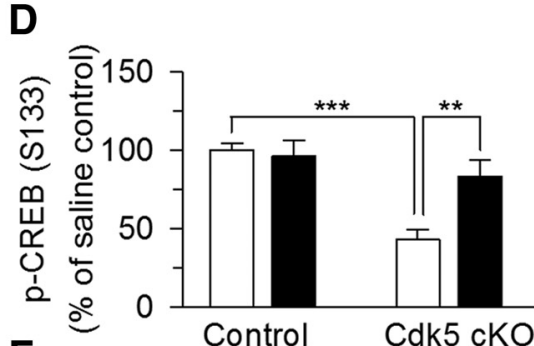

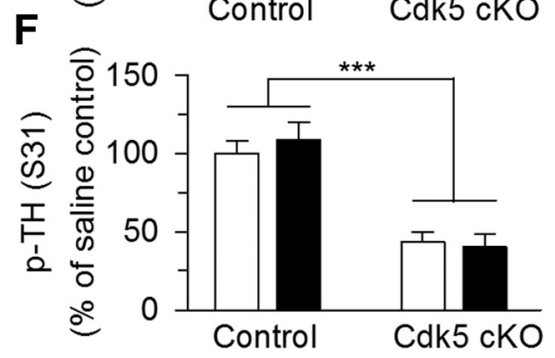

H

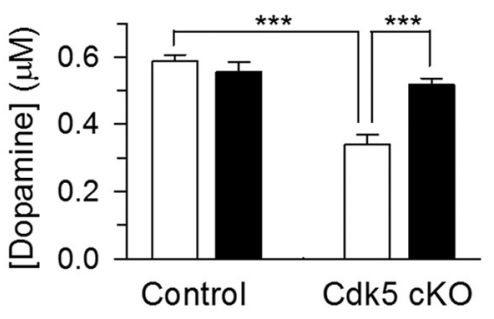

Figure 10. DREADD receptor rM3D-Gs-mediated activation of CAMP/PKA signaling in the VTA of Cdk5 CKO mice. A, Timeline for the AAV injection, ELISA, Western blotting (WB), and FSCV. B, ELISA showing that cAMP levels in the VTA were significantly decreased in C $\mathrm{dk} 5 \mathrm{CKO}$ mice compared with those in control mice $\left({ }^{*} p<0.05\right)$ and CN0 greatly enhanced cAMP levels in Cdk5 $\mathrm{CKO}$ mice $\left({ }^{*} p<\right.$ 0.001). $\boldsymbol{C}-\boldsymbol{F}$, Representative $(\boldsymbol{C})$ and summarized $(\boldsymbol{D}, \boldsymbol{E})$ data of Western blots showing that p-CREB (Ser133; $\boldsymbol{D})$ and $\mathrm{p}$-TH $(\mathbf{S e r} 40 ; \boldsymbol{E})$ levels in the VTA were significantly decreased in $C \mathrm{dk5}$ cK0 mice compared with those in control mice $\left({ }^{* * *} p<0.001,{ }^{* *} p<0.01\right.$ ) and these decreases were reversed by intraperitoneal injection of CNO (** $\left.p<0.01\right)$. In addition, $p$-CREB (Ser133) and $p-$ TH (Ser 40 ) levels were not significantly different between control and Cdk5 cK0 mice that received CNO injections ( $p>0.05$ ). In contrast, $p$-TH (Ser31) levels in the VTA were decreased in Cdk5 cK0 mice $\left({ }^{* * *} p<0.001\right)$ and CNO injection did not significantly affect $p$-TH (Ser31) levels $(p>0.05 ; \boldsymbol{F}) . n=5$ mice/group. Immunoreactivity was normalized to GAPDH and is presented as a percentage of that of control mice with saline injection (saline control). G, Representative traces of FSCV showing the micromolar concentration of dopamine over time in the NAc Shell in response to 5 -pulse electrical stimulation at $30 \mathrm{~Hz}$ (indicated by arrow). $\boldsymbol{H}$, Summarized data of FSCV showing that the average peak concentration of dopamine was significantly decreased in Cdk5 cK0 mice compared with those in control mice $\left.{ }^{* * *} p<0.001\right)$ and these decreases were reversed by $\mathrm{CNO}\left({ }^{* * *} p<0.001\right) . n=9-11$ from 4 mice/group.

p-TH (Ser31) levels in the VTA were decreased in Cdk5 cKO mice, which can be explained by the absence of Cdk5-mediated phosphorylation of TH (Ser31). Interestingly, p- TH (Ser40) levels in the VTA were also significantly decreased in Cdk5 cKO mice. Considering that p-TH (Ser40) is phosphorylated by PKA (Haycock, 1996; Salvatore et al., 2001), we investigated whether the Cdk5 cKO-induced decrease in p-TH (Ser40) levels was caused by impaired cAMP/PKA signaling. Indeed, ELISA showed that the cAMP level was decreased in the VTA tissue of Cdk $5 \mathrm{cKO}$ mice. The expression of $\mathrm{p}-\mathrm{CREB}$, a direct downstream target of cAMP/PKA (Silva et al., 1998), was decreased in the VTA in Cdk5 cKO mice. cAMP is hydrolyzed and inactivated by phosphodiesterases (PDEs; Conti et al., 2003). Proteomic screening revealed that hippocampus-specific $\mathrm{Cdk} 5$ knock-out results in an increase in PDE protein levels and an impairment of cAMP/PKA signaling (Guan et al., 2011), so it is therefore likely that similar mechanisms operate in the VTA in Cdk5 cKO mice, leading to a decrease in phosphorylation of TH (Ser40). It should be pointed out that many molecules other than the cAMP pathway are altered after $\mathrm{Cdk} 5$ deletion, including receptors, channels, and trafficking molecules (Hawasli et al., 2007; Guan et al., 2011). Other pathways may also be involved in biomedical and behavioral changes induced by Cdk5 deletion. Although evaluating other substrates may provide additional information about the number of collected $\mathrm{TH}^{+}$cells and cell types affected by Cdk $5 \mathrm{cKO}$, it is likely that the changes in substrates of cAMP/PKA and Cdk5 mainly originate from dopamine neurons.

TH phosphorylation at Ser40 increases dopamine synthesis, whereas TH phosphorylation at Ser31 had a modest effect on dopamine synthesis (Dunkley et al., 2004). Cdk5 cKO decreased TH phosphorylation at both serine sites, which in turn led to a decrease in dopamine synthesis and release. Indeed, FSCV recordings showed that dopamine release in the NAc shell was significantly decreased in Cdk5 cKO mice. By expressing the DREADD receptor rM3D-Gs in VTA dopamine neurons, we were able to elevate cAMP selectively with cell-type specificity and minimal invasiveness. We found that stimulation of rM3D-Gs with CNO increased cAMP, p-CREB, and p-TH (Ser40) levels, but not p-TH (Ser31) levels, in the VTA and normalized dopamine responses in the NAc in Cdk5 cKO mice. These results suggest that $\mathrm{TH}$ phosphorylation at Ser40 plays a predominant role in dopamine synthesis (Dunkley et al., 2004) or, alternatively, that cAMP-induced TH phosphorylation at Ser40 can maintain dopamine synthesis by overcoming Cdk5 cKO-induced decrease in TH phosphorylation at Ser31. 
A
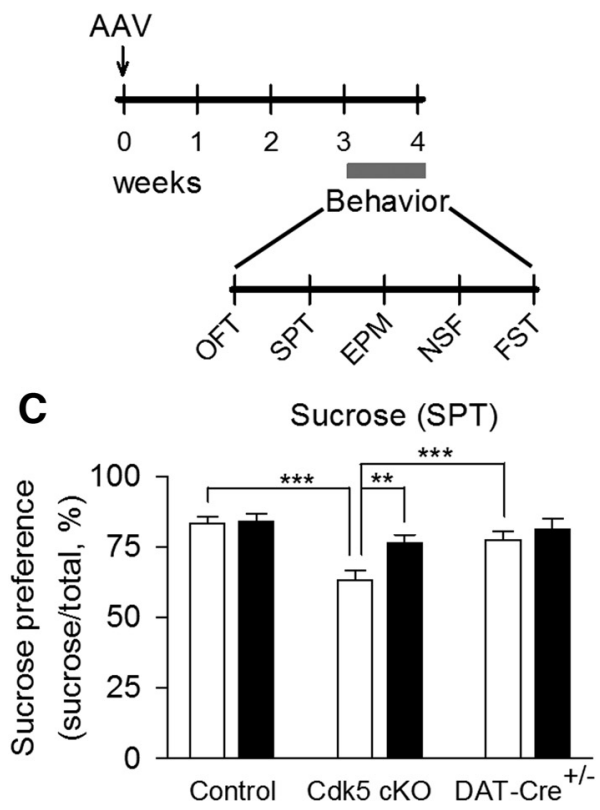

B

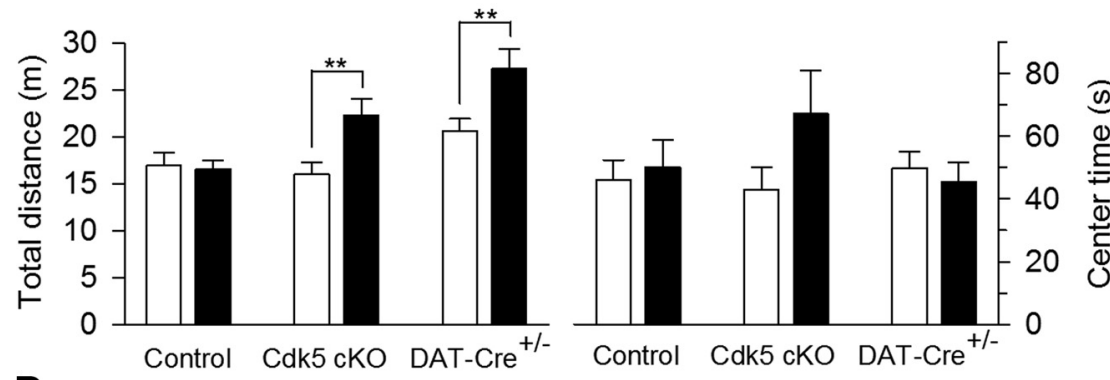

Elevated plus maze (EPM)

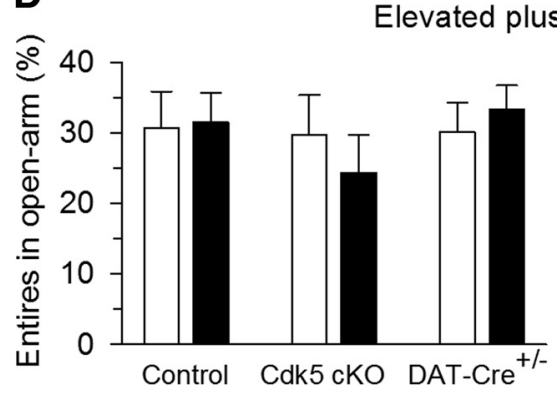

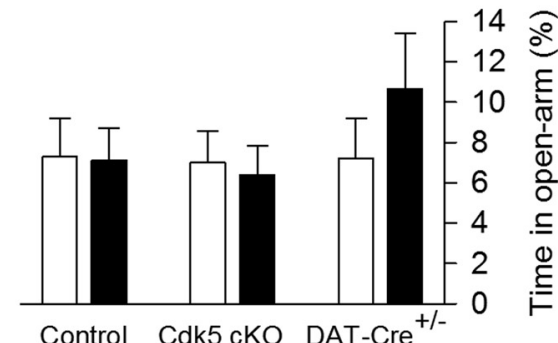

E

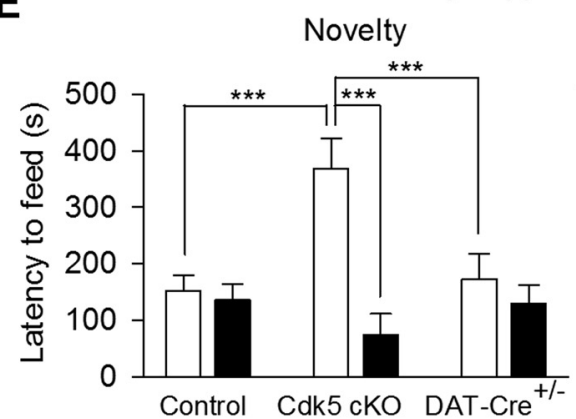

Novelty-suppressed feeding (NSF)

Home

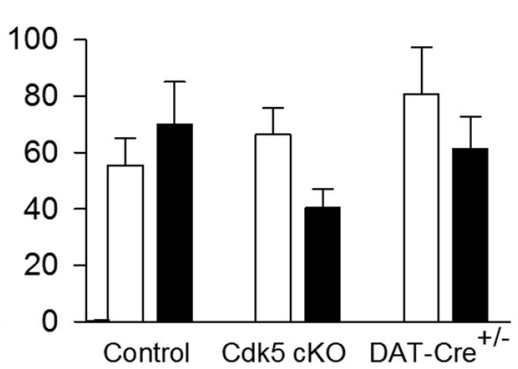

$\mathbf{F}$

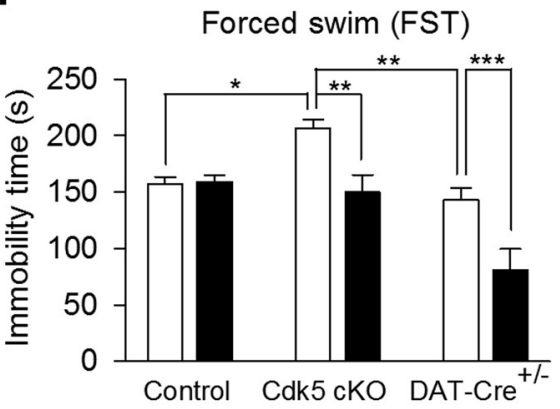

Figure 11. CNO-induced activation of the DREADD receptor rM3D-Gs in VTA dopamine neurons reversed anxiety- and depressive-like behaviors induced by Cdk5 cKO. $A$, Timeline for the AAV microinjection and behavioral tests. $\boldsymbol{B}$, In the OFT CN0, but not intraperitoneal saline injection, increased the total traveled distance in Cdk5 cK0 $\left(^{* *} p<0.01\right)$ and DAT-Cre ${ }^{+/-} / \mathrm{Cdk}^{\mathrm{wt} / \mathrm{wt}}\left({ }^{* *} p<\right.$ 0.01 ) mice without affecting the total traveled distance in control mice $(p>0.05)$. Neither genotype $(p>0.05)$ nor CN0 injection ( $p>0.05)$ altered the center time in the open field. $C$, The sucrose preference was significantly decreased in Cdk5 cKO mice compared with that in control ( $\left.{ }^{* * *} p<0.001\right)$ and DAT-Cre ${ }^{+/-} / \mathrm{Cdk}^{\text {wt }}{ }^{\text {wt }}\left({ }^{* * *} p<0.001\right)$ mice and this decrease was reversed by CN0 injection ( $\left.{ }^{* *} p<0.01\right)$. In addition, CN0 injection did not significantly affect sucrose preference in DAT-Cre ${ }^{+/-} / \mathrm{Cdk} 5^{\text {wt } / \text { wt }}$ mice $(p>0.05)$. D, Neither genotype nor CN0 injection significantly changed the number of entries into the open arms $(p>0.05)$ and the time spent in the open arms $(p>0.05)$ in the EPM test. $\boldsymbol{E}$, In the NSF test, the latency to feed in the novel environment was significantly increased in Cdk5 CK0 mice compared with that in control $\left({ }^{* * *} p<0.001\right)$ and DAT-Cre ${ }^{+/-} / \mathrm{Cdk}^{\text {wt/wt }}\left({ }^{* * *} p<0.001\right)$ mice and this increase was reversed by CN0 injection $\left({ }^{* * *} p<\right.$ $0.001)$. In addition, CNO injection did not significantly affect the latency to feed in DAT-Cre ${ }^{+/-} / \mathrm{Cdk}^{\mathrm{wt} / \mathrm{wt}}$ mice $(p>0.05)$. In contrast, neither genotype $(p>0.05)$ nor CN0 injection $(p>0.05)$ affected the latency to feed in the home cage. $F$, In the FST, the immobility time was significantly increased in $\left(\mathrm{dk} 5 \mathrm{cKO}\right.$ mice compared with that in control $\left({ }^{*} p<0.05\right)$ and DAT-Cre ${ }^{+/-} / \mathrm{Cdk} 5{ }^{\text {wt } / \text { wt }}$ $\left({ }^{* *} p<0.01\right)$ mice and CN0 injection reversed Cdk5 cK0-induced increase in the immobility time $\left({ }^{* *} p<0.01\right)$. However, CNO injection did significantly decrease the immobility time in

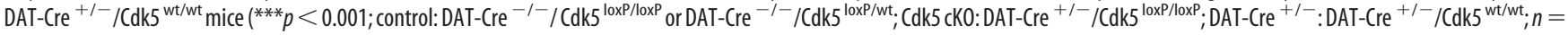
9-10 mice/group).

These results indicate that $\mathrm{Cdk} 5$ positively modulates cAMP/ PKA and dopamine synthesis in the VTA. In contrast, Cdk5 exerts opposite modulation of cAMP/PKA and dopamine signaling in the striatum. Phosphorylation of DARPP-32 at Thr75 by Cdk5 inhibits PKA and activates PP1 (Bibb et al., 1999; Nishi et al., 2000), whereas phosphorylation of DARPP-32 at Thr34 by $D_{1}$ dopamine receptor-mediated activation of PKA inhibits PP1 (Nishi et al., 1997; Svenningsson et al., 1998; Bibb et al., 1999). Therefore, Cdk5 negatively regulates $\mathrm{D}_{1}$ dopamine receptor/PKA signaling in the striatum. In support of this idea, pharmacological inhibition or genetic deletion of Cdk5 in the striatum enhances psychomotor activating and rewarding effects of cocaine and cocaine-seeking behavior (Bibb et al., 2001; Benavides et al., 2007; Taylor et al., 2007). DARPP-32 was not expressed in the
VTA (Ouimet et al., 1992) and the feedback loop in the striatum does not exist in the VTA, which may explain the differential modulation of cAMP/PKA and dopamine signaling between the VTA and striatum.

We have shown that Cdk5 deletion decreased cAMP, p-CREB, and p-TH levels in the VTA and dopamine release in the NAc and induced depressive-like behaviors, whereas activation of rM3D-Gs by CNO reversed most of the biomedical and behavioral changes induced by $\mathrm{Cdk} 5 \mathrm{cKO}$. Although our experimental data are correlative rather than causative, we speculate that the deficits in $\mathrm{TH}$ phosphorylation and dopaminergic transmission might underlie Cdk5 deletion-induced depressive-like behaviors. In addition to $\mathrm{TH}, \mathrm{Cdk} 5$ phosphorylates a large number of substrates (Barnett and Bibb, 2011; Su and Tsai, 2011). For example, 
Cdk5 phosphorylates $N$-type voltage-gated calcium channels, resulting in facilitation of neurotransmitter release via an increase in the number of docked vesicles at the synaptic cleft (Su et al., 2012). Cdk5 cKO may decrease dopamine release by negatively modifying presynaptic $N$-type calcium channels. Our studies do not exclude the possibility that other Cdk 5 targets could be responsible for the behavioral deficits induced by Cdk 5 deletion in the VTA.

Perturbed dopaminergic transmission might play a role in the pathophysiology of depression. In patients with untreated Parkinson's disease, higher depression scores were associated with lower dopamine synthesis capacity in the striatum, as determined by positron emission tomography of $18 \mathrm{~F}$-fluorodopa uptake (Joutsa et al., 2013). The dopamine agonist pramipexole produced antidepressant effects in patients who failed to respond to standard antidepressant treatments (Franco-Chaves et al., 2013). Long-lasting changes in action potential firing pattern, gene regulation, and protein expression occur in the VTA-NAc pathway in several animal models of depression and antidepressant treatment (Shirayama et al., 2004; Berton et al., 2006; Krishnan et al., 2007; Chartoff et al., 2009; Wilkinson et al., 2009; Cao et al., 2010). Optogenetic inhibition of VTA dopamine neurons induces depressive-like behaviors, whereas chronic mild stress induces a depression-like phenotype that is reversed by phasic activation of VTA dopamine neurons (Tye et al., 2013). Conversely, phasic activation of VTA neurons projecting to the NAc induces susceptibility to social-defeat stress and optogenetic inhibition of the VTA-NAc projection induces resilience (Chaudhury et al., 2013). We have shown that Cdk5 loss of function in the VTA decreased TH phosphorylation and dopamine synthesis and release and induced depressive-like behaviors. Together, these results strongly support the idea that the mesolimbic dopamine system is critically involved in mood regulation and its dysfunction underlies the manifestation of depressive-like behaviors.

\section{References}

Alexander GM, Rogan SC, Abbas AI, Armbruster BN, Pei Y, Allen JA, Nonneman RJ, Hartmann J, Moy SS, Nicolelis MA, McNamara JO, Roth BL (2009) Remote control of neuronal activity in transgenic mice expressing evolved G protein-coupled receptors. Neuron 63:27-39. CrossRef Medline

Armbruster BN, Li X, Pausch MH, Herlitze S, Roth BL (2007) Evolving the lock to fit the key to create a family of $\mathrm{G}$ protein-coupled receptors potently activated by an inert ligand. Proc Natl Acad Sci U S A 104:51635168. CrossRef Medline

Bäckman CM, Malik N, Zhang Y, Shan L, Grinberg A, Hoffer BJ, Westphal H, Tomac AC (2006) Characterization of a mouse strain expressing Cre recombinase from the $3^{\prime}$ untranslated region of the dopamine transporter locus. Genesis 44:383-390. CrossRef Medline

Barnett DG, Bibb JA (2011) The role of Cdk5 in cognition and neuropsychiatric and neurological pathology. Brain Res Bull 85:9-13. CrossRef Medline

Benavides DR, Quinn JJ, Zhong P, Hawasli AH, DiLeone RJ, Kansy JW, Olausson P, Yan Z, Taylor JR, Bibb JA (2007) Cdk5 modulates cocaine reward, motivation, and striatal neuron excitability. J Neurosci 27:1296712976. CrossRef Medline

Berton O, McClung CA, Dileone RJ, Krishnan V, Renthal W, Russo SJ, Graham D, Tsankova NM, Bolanos CA, Rios M, Monteggia LM, Self DW, Nestler EJ (2006) Essential role of BDNF in the mesolimbic dopamine pathway in social defeat stress. Science 311:864-868. CrossRef Medline

Bibb JA (2005) Decoding dopamine signaling. Cell 122:153-155. CrossRef Medline

Bibb JA, Snyder GL, Nishi A, Yan Z, Meijer L, Fienberg AA, Tsai LH, Kwon YT, Girault JA, Czernik AJ, Huganir RL, Hemmings HC Jr, Nairn AC, Greengard P (1999) Phosphorylation of DARPP-32 by Cdk5 modulates dopamine signalling in neurons. Nature 402:669-671. CrossRef Medline Bibb JA, Chen J, Taylor JR, Svenningsson P, Nishi A, Snyder GL, Yan Z,
Sagawa ZK, Ouimet CC, Nairn AC, Nestler EJ, Greengard P (2001) Effects of chronic exposure to cocaine are regulated by the neuronal protein Cdk5. Nature 410:376-380. CrossRef Medline

Burn DJ (2002) Depression in Parkinson's disease. Eur J Neurol 9:44-54. CrossRef Medline

Cao JL, Covington HE 3rd, Friedman AK, Wilkinson MB, Walsh JJ, Cooper DC, Nestler EJ, Han MH (2010) Mesolimbic dopamine neurons in the brain reward circuit mediate susceptibility to social defeat and antidepressant action. J Neurosci 30:16453-16458. CrossRef Medline

Chartoff EH, Papadopoulou M, MacDonald ML, Parsegian A, Potter D, Konradi C, Carlezon WA Jr (2009) Desipramine reduces stress-activated dynorphin expression and CREB phosphorylation in NAc tissue. Mol Pharmacol 75:704-712. CrossRef Medline

Chaudhury D, Walsh JJ, Friedman AK, Juarez B, Ku SM, Koo JW, Ferguson D, Tsai HC, Pomeranz L, Christoffel DJ, Nectow AR, Ekstrand M, Domingos A, Mazei-Robison MS, Mouzon E, Lobo MK, Neve RL, Friedman JM, Russo SJ, Deisseroth K, et al. (2013) Rapid regulation of depressionrelated behaviours by control of midbrain dopamine neurons. Nature 493:532-536. CrossRef Medline

Chergui K, Svenningsson P, Greengard P (2004) Cyclin-dependent kinase 5 regulates dopaminergic and glutamatergic transmission in the striatum. Proc Natl Acad Sci U S A 101:2191-2196. CrossRef Medline

Cheung ZH, Ip NY (2012) Cdk5: a multifaceted kinase in neurodegenerative diseases. Trends Cell Biol 22:169-175. CrossRef Medline

Conti M, Richter W, Mehats C, Livera G, Park JY, Jin C (2003) Cyclic AMPspecific PDE4 phosphodiesterases as critical components of cyclic AMP signaling. J Biol Chem 278:5493-5496. CrossRef Medline

Drerup JM, Hayashi K, Cui H, Mettlach GL, Long MA, Marvin M, Sun X, Goldberg MS, Lutter M, Bibb JA (2010) Attention-deficit/hyperactivity phenotype in mice lacking the cyclin-dependent kinase 5 cofactor p35. Biol Psychiatry 68:1163-1171. CrossRef Medline

Duman RS (2007) A silver bullet for the treatment of depression? Neuron 55:679-681. CrossRef Medline

Dunkley PR, Bobrovskaya L, Graham ME, von Nagy-Felsobuki EI, Dickson PW (2004) Tyrosine hydroxylase phosphorylation: regulation and consequences. J Neurochem 91:1025-1043. CrossRef Medline

El Yacoubi M, Bouali S, Popa D, Naudon L, Leroux-Nicollet I, Hamon M, Costentin J, Adrien J, Vaugeois JM (2003) Behavioral, neurochemical, and electrophysiological characterization of a genetic mouse model of depression. Proc Natl Acad Sci U S A 100:6227-6232. CrossRef Medline

Farrell MS, Pei Y, Wan Y, Yadav PN, Daigle TL, Urban DJ, Lee HM, Sciaky N, Simmons A, Nonneman RJ, Huang XP, Hufeisen SJ, Guettier JM, Moy SS, Wess J, Caron MG, Calakos N, Roth BL (2013) A Galphas DREADD mouse for selective modulation of cAMP production in striatopallidal neurons. Neuropsychopharmacology 38:854-862. CrossRef Medline

Franco-Chaves JA, Mateus CF, Luckenbaugh DA, Martinez PE, Mallinger AG, Zarate CA Jr (2013) Combining a dopamine agonist and selective serotonin reuptake inhibitor for the treatment of depression: a doubleblind, randomized pilot study. J Affect Disord 149:319-325. CrossRef Medline

Guan JS, Su SC, Gao J, Joseph N, Xie Z, Zhou Y, Durak O, Zhang L, Zhu JJ, Clauser KR, Carr SA, Tsai LH (2011) Cdk5 is required for memory function and hippocampal plasticity via the cAMP signaling pathway. PLoS One 6:e25735. CrossRef Medline

Guettier JM, Gautam D, Scarselli M, Ruiz de Azua I, Li JH, Rosemond E, Ma X, Gonzalez FJ, Armbruster BN, Lu H, Roth BL, Wess J (2009) A chemical-genetic approach to study $\mathrm{G}$ protein regulation of beta cell function in vivo. Proc Natl Acad Sci U S A 106:19197-19202. CrossRef Medline

Hawasli AH, Benavides DR, Nguyen C, Kansy JW, Hayashi K, Chambon P, Greengard P, Powell CM, Cooper DC, Bibb JA (2007) Cyclindependent kinase 5 governs learning and synaptic plasticity via control of NMDAR degradation. Nat Neurosci 10:880-886. CrossRef Medline

Haycock JW (1996) Short- and long-term regulation of tyrosine hydroxylase in chromaffin cells by VIP and PACAP. Ann N Y Acad Sci 805:219230; discussion 230-231. CrossRef Medline

Johnson SW, North RA (1992) Two types of neurone in the rat ventral tegmental area and their synaptic inputs. J Physiol 450:455-468. Medline

Joutsa J, Rinne JO, Eskola O, Kaasinen V (2013) Reduced striatal dopamine synthesis capacity is associated with symptoms of depression in patients with de novo unmedicated Parkinson's disease. J Parkinsons Dis 3:325329. CrossRef Medline 
Kansy JW, Daubner SC, Nishi A, Sotogaku N, Lloyd MD, Nguyen C, Lu L, Haycock JW, Hope BT, Fitzpatrick PF, Bibb JA (2004) Identification of tyrosine hydroxylase as a physiological substrate for Cdk5. J Neurochem 91:374-384. CrossRef Medline

Kim SH, Ryan TA (2010) CDK5 serves as a major control point in neurotransmitter release. Neuron 67:797-809. CrossRef Medline

Komada M, Takao K, Miyakawa T (2008) Elevated plus maze for mice. J Vis Exp pii:1088. CrossRef Medline

Koo JW, Duman RS (2008) IL-1beta is an essential mediator of the antineurogenic and anhedonic effects of stress. Proc Natl Acad Sci U S A 105:751756. CrossRef Medline

Krishnan V, Han MH, Graham DL, Berton O, Renthal W, Russo SJ, Laplant Q, Graham A, Lutter M, Lagace DC, Ghose S, Reister R, Tannous P, Green TA, Neve RL, Chakravarty S, Kumar A, Eisch AJ, Self DW, Lee FS, et al. (2007) Molecular adaptations underlying susceptibility and resistance to social defeat in brain reward regions. Cell 131:391-404. CrossRef Medline

Moy LY, Tsai LH (2004) Cyclin-dependent kinase 5 phosphorylates serine 31 of tyrosine hydroxylase and regulates its stability. J Biol Chem 279: 54487-54493. CrossRef Medline

Nestler EJ, Hyman SE (2010) Animal models of neuropsychiatric disorders. Nat Neurosci 13:1161-1169. CrossRef Medline

Nestler EJ, Carlezon WA Jr (2006) The mesolimbic dopamine reward circuit in depression. Biol Psychiatry 59:1151-1159. CrossRef Medline

Nishi A, Snyder GL, Greengard P (1997) Bidirectional regulation of DARPP-32 phosphorylation by dopamine. J Neurosci 17:8147-8155. Medline

Nishi A, Bibb JA, Snyder GL, Higashi H, Nairn AC, Greengard P (2000) Amplification of dopaminergic signaling by a positive feedback loop. Proc Natl Acad Sci U S A 97:12840-12845. CrossRef Medline

Ouimet CC, LaMantia AS, Goldman-Rakic P, Rakic P, Greengard P (1992) Immunocytochemical localization of DARPP-32, a dopamine and cyclicAMP-regulated phosphoprotein, in the primate brain. J Comp Neurol 323:209-218. CrossRef Medline

Pan B, Zhong P, Sun D, Liu QS (2011) Extracellular signal-regulated kinase signaling in the ventral tegmental area mediates cocaine-induced synaptic plasticity and rewarding effects. J Neurosci 31:11244-11255. CrossRef Medline

Park SK, Nguyen MD, Fischer A, Luke MP, Affar el B, Dieffenbach PB, Tseng HC, Shi Y, Tsai LH (2005) Par-4 links dopamine signaling and depression. Cell 122:275-287. CrossRef Medline

Patrick GN, Zukerberg L, Nikolic M, de la Monte S, Dikkes P, Tsai LH (1999) Conversion of $\mathrm{p} 35$ to $\mathrm{p} 25$ deregulates $\mathrm{Cdk} 5$ activity and promotes neurodegeneration. Nature 402:615-622. CrossRef Medline

Paxinos G, Franklin KBJ (2001) The mouse brain in stereotaxic coordinates, Ed 2. San Diego: Academic.

Porsolt RD, Le Pichon M, Jalfre M (1977) Depression: a new animal model sensitive to antidepressant treatments. Nature 266:730-732. CrossRef Medline

Price DA, Sorkin A, Zahniser NR (2009) Cyclin-dependent kinase 5 inhibitors: inhibition of dopamine transporter activity. Mol Pharmacol 76: 812-823. CrossRef Medline

Rodgers RJ, Dalvi A (1997) Anxiety, defence and the elevated plus-maze. Neurosci Biobehav Rev 21:801-810. CrossRef Medline

Rogan SC, Roth BL (2011) Remote control of neuronal signaling. Pharmacol Rev 63:291-315. CrossRef Medline

Salvatore MF, Waymire JC, Haycock JW (2001) Depolarization-stimulated catecholamine biosynthesis: involvement of protein kinases and tyrosine hydroxylase phosphorylation sites in situ. J Neurochem 79:349-360. CrossRef Medline

Santarelli L, Saxe M, Gross C, Surget A, Battaglia F, Dulawa S, Weisstaub N, Lee J, Duman R, Arancio O, Belzung C, Hen R (2003) Requirement of hippocampal neurogenesis for the behavioral effects of antidepressants. Science 301:805-809. CrossRef Medline

Schlaepfer TE, Cohen MX, Frick C, Kosel M, Brodesser D, Axmacher N, Joe AY, Kreft M, Lenartz D, Sturm V (2008) Deep brain stimulation to reward circuitry alleviates anhedonia in refractory major depression. Neuropsychopharmacology 33:368-377. CrossRef Medline

Shirayama Y, Ishida H, Iwata M, Hazama GI, Kawahara R, Duman RS (2004) Stress increases dynorphin immunoreactivity in limbic brain regions and dynorphin antagonism produces antidepressant-like effects. J Neurochem 90:1258-1268. CrossRef Medline
Silva AJ, Kogan JH, Frankland PW, Kida S (1998) CREB and memory. Annu Rev Neurosci 21:127-148. CrossRef Medline

Su SC, Tsai LH (2011) Cyclin-dependent kinases in brain development and disease. Annu Rev Cell Dev Biol 27:465-491. CrossRef Medline

Su SC, Seo J, Pan JQ, Samuels BA, Rudenko A, Ericsson M, Neve RL, Yue DT, Tsai LH (2012) Regulation of $N$-type voltage-gated calcium channels and presynaptic function by cyclin-dependent kinase 5. Neuron 75:675687. CrossRef Medline

Su SC, Rudenko A, Cho S, Tsai LH (2013) Forebrain-specific deletion of $\mathrm{Cdk} 5$ in pyramidal neurons results in mania-like behavior and cognitive impairment. Neurobiol Learn Mem 105:54-62. CrossRef Medline

Svenningsson P, Lindskog M, Rognoni F, Fredholm BB, Greengard P, Fisone G (1998) Activation of adenosine A2A and dopamine D1 receptors stimulates cyclic AMP-dependent phosphorylation of DARPP-32 in distinct populations of striatal projection neurons. Neuroscience 84:223228. CrossRef Medline

Taylor JR, Lynch WJ, Sanchez H, Olausson P, Nestler EJ, Bibb JA (2007) Inhibition of Cdk5 in the nucleus accumbens enhances the locomotoractivating and incentive-motivational effects of cocaine. Proc Natl Acad Sci U S A 104:4147-4152. CrossRef Medline

Tomizawa K, Ohta J, Matsushita M, Moriwaki A, Li ST, Takei K, Matsui H (2002) Cdk5/p35 regulates neurotransmitter release through phosphorylation and downregulation of $\mathrm{P} / \mathrm{Q}$-type voltage-dependent calcium channel activity. J Neurosci 22:2590-2597. Medline

Tripp G, Wickens JR (2009) Neurobiology of ADHD. Neuropharmacology 57:579-589. CrossRef Medline

Tye KM, Mirzabekov JJ, Warden MR, Ferenczi EA, Tsai HC, Finkelstein J, Kim SY, Adhikari A, Thompson KR, Andalman AS, Gunaydin LA, Witten IB, Deisseroth K (2013) Dopamine neurons modulate neural encoding and expression of depression-related behaviour. Nature 493:537-541. CrossRef Medline

Wallace DL, Han MH, Graham DL, Green TA, Vialou V, Iñiguez SD, Cao JL, Kirk A, Chakravarty S, Kumar A, Krishnan V, Neve RL, Cooper DC, Bolaños CA, Barrot M, McClung CA, Nestler EJ (2009) CREB regulation of nucleus accumbens excitability mediates social isolation-induced behavioral deficits. Nat Neurosci 12:200-209. CrossRef Medline

Wang W, Sun D, Pan B, Roberts CJ, Sun X, Hillard CJ, Liu QS (2010) Deficiency in endocannabinoid signaling in the nucleus accumbens induced by chronic unpredictable stress. Neuropsychopharmacology 35:22492261. CrossRef Medline

Wightman RM (2006) Detection technologies. Probing cellular chemistry in biological systems with microelectrodes. Science 311:1570-1574. CrossRef Medline

Wilkinson MB, Xiao G, Kumar A, LaPlant Q, Renthal W, Sikder D, Kodadek TJ, Nestler EJ (2009) Imipramine treatment and resiliency exhibit similar chromatin regulation in the mouse nucleus accumbens in depression models. J Neurosci 29:7820-7832. CrossRef Medline

Willner P, Towell A, Sampson D, Sophokleous S, Muscat R (1987) Reduction of sucrose preference by chronic unpredictable mild stress, and its restoration by a tricyclic antidepressant. Psychopharmacology 93:358 364. Medline

Yan Z, Chi P, Bibb JA, Ryan TA, Greengard P (2002) Roscovitine: a novel regulator of $\mathrm{P} / \mathrm{Q}$-type calcium channels and transmitter release in central neurons. J Physiol 540:761-770. CrossRef Medline

Yorgason JT, España RA, Jones SR (2011) Demon voltammetry and analysis software: analysis of cocaine-induced alterations in dopamine signaling using multiple kinetic measures. J Neurosci Methods 202:158-164. CrossRef Medline

Yu F, Zhong P, Liu X, Sun D, Gao HQ, Liu QS (2013) Metabotropic glutamate receptor I (mGluR1) antagonism impairs cocaine-induced conditioned place preference via inhibition of protein synthesis. Neuropsychopharmacology 38: 1308-1321. CrossRef Medline

Zhong P, Wang W, Pan B, Liu XJ, Long JZ, Zhang HT, Cravatt BF, Liu QS (2014) Monoacylglycerol lipase inhibition blocks chronic mild stressinduced depressive-like behaviors via activation of mTOR signaling. Neuropsychopharmacology. Advance online publication. Retrieved Jan. 30, 2014. doi:10.1038/npp.2014.24. CrossRef Medline

Zhu WL, Shi HS, Wang SJ, Xu CM, Jiang WG, Wang X, Wu P, Li QQ, Ding ZB, Lu L (2012) Increased Cdk5/p35 activity in the dentate gyrus mediates depressive-like behaviour in rats. Int J Neuropsychopharmacol 15: 795-809. CrossRef Medline 